\title{
FACTIONS AND NATIONS: IDENTITY \\ AND IDENTIFICATION IN THE HISTORICAL VIDEO GAMES SET IN THE MIDDLE AGES
}

\author{
Juan Francisco Jiménez Alcázar \\ Universidad de Murcia \\ SPAIN
}

Date of receipt: $1^{\text {st }}$ of February, 2021

Date of acceptance: $9^{\text {th }}$ of March, 2021

\section{Abstract}

Historical video games offer players the opportunity to choose different options for managing factions and nations of the past, with which they can come to identify. The interactive and immersive nature of the medium makes this possible, and the thrill of winning or losing is enhanced by this ability to assimilate. The study focuses on those set in the medieval period, where factions respond to the various historical stages that define it. In this identity process through the video game, the player assumes a virtual role in which individual or group feelings that historically define their identity are reflected. These titles, as products of cultural expression, are also manifestations of those who have designed them, and inaccuracies due to cultural clichés or factors to be more entertaining - playability- are often resolved by gamers through the mod phenomenon.

KEY WORDS

Historical video game, Middle Ages, Identity, Nation, Avatar.

\section{Capitalia verba}

Historicorum Videoludi, Medium Aevum, Identitas, Natio, Locumtenens. 


\section{Options}

We must not insist on the fact that video games are a reality. It is not necessary, regardless of the position one may hold in principle about this phenomenon.

Video games are a medium that came to stay and their globalization is already a fact. We can find for and against, scientific and pseudoscientific, studies which show factors about their advantages as excellent experiences and in the development of skills and knowledge; and, at the same time, they are not recommended because of how addictive they are, the intrinsic violence detected in them, and because they are a major waste of time. Everything is really ironic, as we must assume that this channel of cultural expression is to be used as any other thing: common sense and moderation are a priority and, as any other technological tool, their correct management is essential to avoid any excesses and misuses. But video games are not the Evil One's invention and they are not an educational solution either, as they can be wrongly understood in one direction and the other. This explanation is necessary: I would not have had to make it if this study dealt with an analysis of the historical novel or, more paradigmatically, of cinema with a screenplay set in a historical past. This issue should make us reflect on the stubborn position we can hold concerning the vertiginous changes we have been witnessing over the recent years. ${ }^{2}$ We can close our eyes and deny them, or be curious and, if we do not participate, at least watch the phenomenon passively and observe it with a certain interest. It is also true that we are dealing with a totally unknown medium for many historians, who look at it more like a problem than a future possibility. ${ }^{3}$ This is not criticism: it is an issue that will be solved in future years, when those "future specialists", the medievalist gamers ${ }^{4}$ will write the Medieval History and see the limits and potential of this channel as a cultural expression and knowledge transmission.

1. 1. This work is framed in the Research group digital humanities: History and videogames financed by the Universidad de Murcia [ref.: E041-06]. Some of the information offered and which can be seen in certain video games can be watched in the screen shot gallery of the web site of the research group "Humanidades Digitales: Historia y Videojuegos" from the Murcia University, <https://www. historiayvideojuegos.com>. All the screen shots that appear in the research study are by the author.

2. I made some reflections on this issue in "Medievalismo, humanidades digitales y los músicos del "Titánic»", Humanidades digitales y videojuegos, Juan Francisco Jiménez, Gerardo Rodríguez, Stella Massa, coords. Murcia: Editum, 2020: 75-90. There are a lot of opinions in this respect, but I consider of great interest the text by Benvenuto, Sergio. "Estizzazione. La nostra vita dopo il coronavirus", Doppiozero, 28 January 2021. <https://www.doppiozero.com/materiali/estizzazione-la-nostra-vita-dopo-il-coronavirus>. 3. For example, an excellent medievalist like José María Monsalvo Antón closes his chapter about the perception of the Middle Ages, "in the time of mass culture", with the following assertion: "These new media [referring to video games and comics] today seem more prone than literature and cinema to present the Middle Ages far away from historical reality - the reality professional historiography is attempting to build". ("Estos nuevos soportes [se refiere al videojuego y al cómic] parecen hoy más propensos que la literatura y el cine para presentar una Edad Media muy alejada de la realidad histórica, la que se intenta construir por la historiografía profesional"). Monsalvo Antón, José Maria. Edad Media y medievalismo. Madrid: Síntesis, 2020: 48.

4. Jiménez Alcázar, Juan Francisco, "Medievalist gamer, un nuevo tipo de historiador", De la Edad de los Imperios a la Guerra Total: Medievo y videojuegos. Murcia: Centro de Estudios Medievales de la Univ. Murcia, 2016: 196-218. <https://historiayvideojuegos.com/wp-content/uploads/attachments/51.pdf.>. 
We assume, therefore, that this medium has been incorporated into our various ways of expressing culture and entertainment, and is being produced mostly out of economic interests of companies, whether multinational or small initiatives -indie - intending to generate added value, that is, money. Another parallel phenomenon is that of the video games made with purposes which are not really identified with entertainment but with learning or experimenting. We know these as "serious games". ${ }^{5}$ Finally, although they are the least numerous of all, we find those produced for various reasons, like for a personal catharsis, as is the case of That Dragon, Cancer (Numious Games, 2016), which got a prize at the 2016 Games Awards; ${ }^{6}$ or even those that seek to stir the user's emotions from diverse perspectives. ${ }^{7}$ After this appraisal has been made, we must resume the indication that it is possible to find titles that have the historical past as the background for their playscript. For Venegas Ramos, a historical video game is "any work that incorporates elements of historical consideration". ${ }^{8}$ It is a precise definition, as its extent encompasses all the possibilities. We can extend it further with several factors to situate that "historical" video game, ${ }^{9}$ which is defined as a production containing truthfulness in whatever is seen, heard and read; which also wields plausibility as an essential part of its development, that is, the things handled by the user in the video game could be plausible. In the third place, avideo game must contain historical information specifically, whether in pictures or text. And finally, the essence of the medium is that its user must be free to play. It is basic that it must be understood as a game experience, where the video gamer's role is what makes the phenomenon successful. A video game needs that freedom to be played, as it is part of its intrinsically immersive character.

Regardless of the fact that it can be practised in a group - multi gamer-, that particular involvement is just what drives us to address the analysis of video games

5. Iuppa, Nick, Borst, Terry. Story and Simulations for Serious Games: Tales from the Trenches, Focal Press, Taylor \& Francis Group. López Raventós, Cristian. “El videojuego como herramienta educativa. Posibilidades y problemáticas acerca de los serious games", Apertura: Revista de Innovación Educativa, 8-1 (2016). Hinojal, Hernán. "El uso de simuladores en el aula universitaria y los serious games", e-Tramas, 1, (2018) <http:// e-tramas.fi.mdp.edu.ar/index.php/e-tramas/article/view/10/12>. Massa, Stella Maris, “Educación con videojuegos: nuevos desafíos". El videojuego en el aula de ciencias y humanidades, Juan Francisco Jiménez, Gerardo Rodríguez, Stella Massa, coords. Murcia: Editum, 2018: 69-88, especially 72-74.

6. Cristian Miranda. "'That Dragon, Cancer', el premiado vídeojuego que narra los instantes finales de un niño con enfermedad terminal". Elmostrador. 3 diciembre 2016. El Mostrador. 28 enero 2021 <https://www.elmostrador.cl/agenda-pais/vida-en-linea/2016/12/03/that-dragon-cancer-el-premiadovideojuego-que-narra-los-instantes-finales-de-un-nino-con-enfermedad-terminal/>.

7. Laura Gómez's article on this phenomenon is quite interesting: “Desde ser un niño con cáncer a un refugiado de guerra: los videojuegos se han hecho muy adultos". Xataka, 4 febrero 2016. <https:// magnet.xataka.com/nuestro-tsundoku/desde-ser-un-nino-con-cancer-a-un-refugiado-de-guerra-losvideojuegos-se-han-hecho-muy-adultos>.

8. Venegas Ramos, Alberto. Pasado interactivo. Memoria e Historia en el videojuego. Vitoria: Sans Soleil Ediciones, 2020: 33.

9. This more extensive definition of the elements that delimit a "historical video game" can be seen in Jiménez Alcázar, Juan Francisco. Juego y ocio en la Historia. Valladolid: Ediciones de la Universidad de Valladolid-Instituto de Historia «Simancas», 2018: 158 and following (Chapter: "La Historia vista a través de los videojuegos"). 
as an identity element. This may be surprising if we say it just like that. But it is not so much when we are to answer three very simple questions: what options are available?, that is, how do those factions appear in the various video games? Why does the gamer choose to play that particular game?; and, finally, why does the user opt for a faction, a country or a character? Besides, those questions must be asked in that order. In opinion articles, whether in specialised publications or in the general press, it is usually stated that the main feature that distinguishes the medium is the gamer's active character. It is true. Some years ago, Enrique García's analysis for Meristation on the study by Andy Przybylski - University of Essex- expressly set out that the key issue in a video game is the possibility for the user to virtually embody their "ideal alter ego".${ }^{10}$ Of course, we must point out that that idealisation is not always to be linked to kind models who are the champions of admirable values. We must point out that it is a wish, a longing, to go through life experiences - let me insist: always virtually - which would not be possible otherwise. The life experience of the past is one of those aspirations, either as a simple curiosity to be just present in past times or as a kind of an atoning exercise in the virtual story: "what... if it had been otherwise"; "what... if I had taken another path..., another decision?" 11 This is part of the crux of this study, as if the game

10. García, Enrique, "Estudio: los juegos divierten porque permiten ser «otro yo ideal»", Meristation, 6 febrero 2015. <https://as.com/meristation/2011/08/09/noticias/1312890840_093676.html>.

11. Fiction journeys into the past, or into the future, both in cinema and televisión as well as in novels form almost a category in themselves from The Time Machine, director George Pal, 1960 (in Spanish, El tiempo en sus manos), including The Time Machine (La máquina del tiempo), director Simon Wells, 2002), an adaptation of Georges Wells' novel, as far as Dr. Who (26 seasons so far), with a long line in between, like Time after Time (Los pasajeros del tiempo) (1979); The Final Countdown (El final de la cuenta atrás) (director Don Taylor, 1980); Time Bandits (Los héroes del tiempo) (director Terry Gilliam, 1981); Les visiteurs (Los visitantes ino nacieron ayer!) (director Jean Marie Poiré, 1993); the sagas Terminator and Back to the Future (Regreso al Futuro); Edge of Tomorrow (Al filo del mañana) (director Doug Liman, 2014); Frequency (director Greogory Hoblit, 2000); 12 Monkeys (Doce monos) (director Terry Gilliam, who, again, resumed the topic with this 1996 film); Planet of the Apes (El planeta de los simios) (director Franklin Schaffner, 1968, and its homonymous remake director Tim Burton, 2001); besides all those produced in the 1970s and in recent years, like Looper (in Spanish Looper, and Looper: asesinos del futuro) (director Rian Johnson, 2012); Interstellar (director Christopher Nolan, 2014); Predestination (directors Michael Spierig and Peter Spierig, 2014); Tenet (director Christopher Nolan, who, like Gilliam, carried on with the subject in 2020); and, going through the game with a time factor, Groundhog Day (Atrapado en el tiempo) (director Harold Ramis, 1993), which has become an important element in our culture. Perhaps the best known novel about this is Mark Twain's A Connecticut Yankee in King Arthur's Court (Un yanqui en la corte del rey Arturo), which would be made into a film; as well as that by Chrichton Timeline (Rescate en el tiempo), which would also be adapted for film with the same title (director Richard Donner, 2003); The End of Eternity (El fin de la eternidad), by Isaac Asimov; The Time Traveler's Wife (La mujer del viajero en el tiempo) by Audrey Niffenegger, also produced as a film (director Robert Schwentke, 2009), etc. I cannot fail to mention what has been one of the great successes of Spanish television, El Ministerio del Tiempo (The Ministry of Time) (director Javier Olivares), which has been running for four seasons so far, starting in 2015, and has adaptations in other countries. The pressure of its viewers led to extend its seasons. The movement of the "ministéricos" can be seen at <https://es.wikipedia.org/wiki/El_Ministerio_del_Tiempo>. La Chica de Ayer (Yesterday's Girl) (directors Ignacio Mercero, Álvaro Ron, Alfonso Arandia, José Ramos, José Paíno, 2009) was not so successful with the media, although travelling in time was only the excuse to situate its main character, Ernesto Alterio, in Transition Spain. We can see Stephen King's novel 11/22/63, not as a different kind of story referring to a crucial moment in the past. It was also made into a television miniseries (dir. K. 
implies a series of decisions, the choice of who to play with in the broad sense of this expression - who we share the game with and which of the factions or characters we choose- is decisive in the background of what we think, assume or, ultimately, identify ourselves with.

We must also point out that, in a general sense, the recreation, or re-creation, of the past in a video game allows for that unattainable aspiration of "travelling to another time". That is why the gaming experience becomes a personal development exercise and responds in the same way to what has been mentioned above concerning that wish for travelling to other historical periods, including ideas to alter the present through some intervention in past events. ${ }^{12}$ Thus alternative, virtual, counterfactic or counterfactual history becomes another of the elements attracting the user, as one of the most common imagination exercises in human beings is executed and crucial in a lot of playscripts for video games. ${ }^{13}$

Therefore, as soon as we face the challenge of a video game, any of them, we are in front of an overview of options. When we have either A or B, we can call it a binary "manichaean decision", but the approach becomes more complicated when there is a greater number of options. Basically, the multiplicity of those paths can be summarised in what a joystick is: depending on where it is directed, there the immediate result will go. It is not a question of using that simile with the diversity of buttons and their combination on a gamepad or a keyboard, but in the

MacDonald, 2016). Les revenants (2012) is also outstanding; it had a "remake», The Returned, which was cancelled in the first season (2015). About this see <https://es.wikipedia.org/wiki/The_Returned (serie_de_televisi\%C3\%B3n_de_2015)>. Among the successes of the Nordic sagas, Beforeigners (Los visitantes), HBO, 2019) is worth mentioning; in it ancient Viking settlers appear in present day and are to be integrated into contemporary social models - a clear reference to the assimilation process of the immigrants most European countries are receiving currently. Mention should be made as well of Diana Gabaldon's Outlander series, which was premiered in 2014 and ran through five seasons as the product of some of her novels, starring Claire Beauchamp and Jamie Fraser. There are other interesting novels like James Gleick's Time Travel, a History (Viajar en el tiempo) and Joyce Carol Oates' Hazards of Time Travel (Riesgos de los viajes en el tiempo). We are missing a lot of novels, films and TV series, but this could become an unending note; so it is only intended as a mere approximation.

12. This active intervention in the past to ammend present issues has been greatly successful, and since the release of the mentioned trilogy, Back to the future, there are not only its corresponding video games (Back to the Future: The Game, Telltale Games, 2010, with five episodes: It's About Time; Get Tannen!; Citizen Brown; Double Visions and OUTATIME): it also has a series of comics and even a specific collection of merchandising, including Playmobil products - a co-creation fan phenomenon. About this issue, see Abad Ruiz, Bárbara. “Transmedia y fenómeno fan: la co-creación en el mundo de los videojuegos". Historia y videojuegos: el impacto de los nuevos medios de ocio sobre el conocimiento histórico. Juan Francisco Jiménez, Íñigo Mugueta, Gerardo Rodríguez, coords. Murcia: Centro de Estudios Medievales de la Universidad de Murcia, 2016: 69-103. <https://historiayvideojuegos.com/wp-content/uploads/attachments/37.pdf>. It has become a cultural referent from the 1980s which still attracts teenagers: they see themselves reflected in the idea of assuming Marty McFly's role and observe what their parents did when they were young.

13. Venegas Ramos, Alberto. “La contrafactualidad de los videojuegos". Zehngames, 13 November 2013. <http://www.zehngames.com/articulos/lacontrafactualidad-de-los-videojuegos/>. Jiménez Alcázar, Juan Francisco. “La historia no fue así: reflexiones sobre el fenómeno de la historia contrafactual en los videojuegos históricos". CLIO. History and History Teaching, 44 (2018): 94-113. On this general issue, see Evans, Richard. Contrafactuales. ¿Y si todo hubiera sido diferente? Madrid: Turner, 2018. 
action of pressing, of deciding. In fact, the arcade category bases its definition on this procedural system. A video game implies a chain of decisions ${ }^{14}$ which can be observed as a series of limitations, because the rules are the guidelines that situate those thresholes before the gamer's potential dispositions. ${ }^{15}$ In fact, the decisionmaking is facilitated by those limits, which also contribute to the game development, where they even complicate or simplify it. ${ }^{16}$ We can refer to the "game theory" as based on decision-making and the process results, but I am not going to dwell on this issue. ${ }^{17}$ Once this decision-making fact has been assumed, I intend to come to the moment when one of its links is transformed into an emotional issue - not a physical one. It is at that moment when we choose to play a role, a format, an appearance, in order to outline an avatar $^{18}$ - to look the same ${ }^{19}$ - a faction... This study is not based on discretionary attitudes when choosing a kind of weapon or a combo at a combat game but on "seeing" a world reflected through the looking glass which comforts the video gamer. That image is the identification the game is seeking in order to attain the intended experience. This process is definitive as it becomes an identity making process, although it may be only in a virtual, fleeting, momentary way. Many times the question is not seeing it in a simple way but the application, conscious or not, of a number of preconceived factors which define a player and, by extension, a video gamer. The negation "not to want something" or "not to want to be" is a decision in itself. Pérez Latorre entitles one of his chapters in a very vivid way, "to be a child or a gangster", referring to the analysis of Grand Theft Auto (RockStar, 1997) ${ }^{20}$. It is at this choosing level where this study should be placed. The empathy or repulsion towards a character, fictitious or not, or towards a faction, made up or not, is what imposes the final choice. This process, usually short, is understood when it is decided by a group. There are times when the sharing of values and the knowledge of the limits generate that identitary idea and

14. “Da igual si es de forma implícita o explícita: todos los videojuegos consisten en tomar decisiones. No siempre es evidente, porque estas son cosas que damos por sentadas, pero si estás pensando en cómo saltar ese pozo sin fondo, estás tomando una decisión. Si no tienes claro qué arma es mejor para hundir pechos, si la escopeta o la ametralladora, estás tomando una decisión. Nuestra mera presencia ya implica que el videojuego es un espacio de constante toma de decisiones, porque de nosotros depende hasta el ritmo". Altozano, José ("Dayo"). El videojuego a través de David Cage. Sevilla: Héroes de Papel, 2017: 149.

15. It is an MDA process (mechanics, dynamics and aesthetics framework). See Planells, Antonio José. “Diseño de juegos orientado al sistema lúdico". Game e Play. Diseño y análisis del juego, el jugador y el sistema lúdico, Daniel Aranda, ed. Barcelona: Universitat Oberta de Catalunya, 2015: 88 and following.

16. What makes a game possible is its rules. Lacasa, Pilar. Los videojuegos. Aprender en mundos reales $y$ virtuales. Madrid: Morata, 2011: 21. Pérez Latorre, Oliver. El lenguaje videolúdico. Análisis de la significación del videojuego. Barcelona: Laertes, 2012: 38. Tost, Gina and Boira, Oriol. Vida extra. Los videojuegos como nunca los has visto. Barcelona: Grijalbo, 2015: 103.

17. Restrepo Carvajal, Carlos Alberto. “Aproximación a la teoría de juegos". Revista Ciencias Estratégicas, 17-22 (2009): 157-175.

18. Navarro Remesal, Víctor. "Ser todo, ser nada: la subjetividad en el videojuego más allá del avatar". Tropelías: Revista de teoría de la literatura y literatura comparada, 31 (2019): 156-173.

19. Juul, Jesper, Half-Real. Video Games between Real Rules and Fictional Worlds. Cambridge (Mass): The MIT Press, 2011: 55 and following.

20. Pérez Latorre, Oliver, El lenguaje videolúdico...: 161. 
the gamers assume that they belong to that same community; we must insist on the team concept. ${ }^{21}$ On many an occasion it does not respond to a specific criterion but it is "likeable" to us because of a number or reasons. On other occasions it is decided by "inheritance" —we are what our grandfather, father or big brother...-, by a more general identification with a clique or more global one with a generation, clan, tribe, nucleus, town, small or large region, or country. ${ }^{22}$ Such referents, which can take any form, end up by generating the determinant factors of an identitary profile which is more or less precise.

In a different sense, it is worth raising the reflection of the gamer phenomenon as an identitary factor. Muriel alludes to the fact that "gamer is not an identity in crisis, it is an identity born from an identity crisis, and, therefore, it remains in a state of quantum uncertainty". ${ }^{23}$ We do not know if this situation as "Schrödinger cats" sets the game player in "no man's land", but it is an issue that, as pointed out above, draws a more cleared landscape as the gamers age and stop identifying the medium as something exclusive for children or teenagers.

\section{The Links as Identity Factors}

A further step in the profile of this process is that of the identity with a past which has shaped us as individuals or as members of a group in its most tribal facet, regardless of the size of the group. It is here where the past as a general idea gains prominence. Globally, the links that can be generated, or are already existing, between various individuals, are the germ of the group as there can arise trust ${ }^{24}$ and neighbourly ${ }^{25}$ bonds, as well as a sense of sharing the same communication

21. Lacasa, Pilar, Los videojuegos...: 22.

22. The socialisation encouraged by video games is what has also made the medium into generational referent. Tisseron, Serge. Internet, videojuegos, televisión... Manual para padres preocupados. Barcelona: Graó, 2004: 122-123.

23. Muriel, Daniel. Identidad Gamer. Videojuegos y construcción de sentido en la sociedad contemporánea. Barcelona: Anaitgames, 2018: 55.

24. Tost, Gina and Boira, Oriol, Vida extra. Los videojuegos como nunca los has visto, Barcelona: Grijalbo, 2015: 30 .

25. Bourin and Durand refer to this factor in order to define "rural solidarities" in the Middle Ages. "Las solidaridades rurales eran, esencialmente, lazos de vecindad. En principio consideraremos los lazos de la población rural como un todo, sin tener en cuenta las diferencias que introdujo la especialización artesanal o profesional (frente a la gran mayoría formada por granjeros), ni las diferencias debidas a los distintos períodos temporales. Desde este punto de vista, la vecindad constituye un dato fundamental pues es indicio de una sociedad de gentes conocidas donde el comportamiento de cada individuo resulta predecible y transparente para los demás, lo cual constituye un rasgo peculiar de la sociedad aldeana". Bourin, Monique and Durand, Robert. "Forasteros y vecinos". La Edad Media a debate, Lester Little, Barbara Rosenwein, eds. Madrid: Akal, 2003: 289. As for urban identities, an obligatory reference is that of José Antonio Jara Fuente. "Introducción". Ante su identidad. La ciudad hispánica en la Baja Edad Media, José A. Jara (coord.). Cuenca: Universidad de Castilla-La Mancha, 2013: 11-24; and also in the same volium: "Identidad política urbana: una reflexión sobre las políticas comunitarias y las identidades comunitarias en la Castilla urbana del siglo XV": 93-115. 
signs, in a very broad sense and not only linguistic. In our culture, it has become more and more commmon to accept this kind of groupings joined together around an adimiration or identification icon, ${ }^{26}$ expressed on many an occasion by the fan phenomenon carried to all relevant parts, like that of the cosplay world. For example, in the case of the Assassin's Creed, a video game that has generated a whole saga of unquestionable vigour, where the development and distribution company, Ubisofot, markets a new title every two years approximately, ${ }^{27}$ we must take note that a production that has a historical background generates characters creating those identifications; but it is not its actual background -let us not forget that it is about assassins - but its outer appearance: dressing like Altaïr or having any figure from his extensive merchandising is the sign of belonging to that fan group. ${ }^{28}$ The outer appearance in relation to that "identity" is quite important, as it remains at a surface level and does not go into the essence of being, into that of wanting to be, or thinking of being. The reference to that past in the configuration of the group or individual identity is an issue intrinsic to the definition of the process, as that same code is part of that general iconography which outlines the identity limits of the group. The origin of what "one is" requires recuperation of the memory and the icons that condition it -mostly subjective referents. We must differentiate between the fact in itself and the memory it generates, since this, by definition, is the result of a particular experience, or, in other words, of how one has lived, seen or heard. In this sense, the role of tradition is also quite important, as oral, written or visual history ultimately generates those models — sometimes, mere distorted reflections of what happened.

Therefore, it is quite interesting to present the video gamer's positioning when trying to intervene in the game. Any of us, on reading a story in the form of a novel, a fictional story, a film, a TV series or a theatre play, ends up "positioning" ourselves according to the affinities, likes and dislikes we have with respect to the characters, in a litteral non pejorative sense -ultimately, we empathise or not with them. It is the ideas that make up our essence, our identity as a group or as individuals, what makes us react. The basic perception of good and evil, without going into the subject in depth considering each civilisation, is just as significant as that of protection or survival. The alleged attacks, physical or not, on another person become our own just because of that identification we make with the person or with the group;

26. Esnaola Horacek, Graciela Alicia. La construcción de la identidad a través de los videojuegos: un estudio del aprendizaje en el contexto institucional de la escuela. Valencia: University of Valencia (PhD Dissertation), 2005. <https://redined.mecd.gob.es/xmlui/handle/11162/16760>. Anyó Sayol, Lluís. "Identidad y videojuego: aplicación de la "Grid Group Cultural Theory" a la etnografía virtual". La mediación tecnológica en la práctica etnográfica, Elisenda Ardévol Piera, Adolfo Estalella and Daniel Domínguez Figaredo (coords.). San Sebastián: Ankulegi, 2008: 151-166 <https://www.ankulegi.org/wp-content/ uploads/2012/03/0510Anyo.pdf>.

27. The latest Assassin's Creed. Valhalla (2020) is evidence of this.

28. Jenkins, Henry. Fans, blogueros y videojuegos. La cultura de la colaboración. Barcelona: Paidós, Barcelona, 2013. Wirman, Hanna. "Sobre la productividad y los fans de los juegos". Aprovecha el tiempo y juega. Algunas claves para entender los videojuegos, Daniel Aranda, Jordi Sánchez-Navarro, eds. Barcelona: Universitat Oberta de Catalunya, 2009: 145-184. 
here we would have to resume the "tribe" factor as an anthropological question which would explain a great deal of the whole process. I am not going to dwell either on this issue, but it is worth noting for the final purpose of the present work. To this effect, it is an essential premise to define what we should understand as "identity" and "identification", in order to understand and locate the objectives of this work. ${ }^{29}$ They are not concepts which are far away from us, since theye are intrinsic characters of what we are and seem. The communicative act itself is an inherent proof of the identification process, as we can say that "there are some who identify video games and isolation" ${ }^{30}$ and merge into a single term various concepts, whether real or not, questionable or not, always according to the particular or collective culture of the one that presents an assertion of those characteristics. I shall not go either into gender dynamics, since that "identity" is more complex and originates a lot of edges, which are not the objectives of this analysis. ${ }^{31}$ For the purpose of it, then, the concept of identity is defined as the idea recognised by a community of people, variable in size, which links specific internal referents to the concreteness and delimitation of the group, where emotions are an inseparable part of that identitary issue. Identification is a development that precedes identity, as it remains in the most visible aspect, the outer one, whether physical or not. Let us not forget that we are analysing the impact of a channel of cultural and entertainment expression concerning average users, who, in principle, have no other interest than entertainment. Quite a different thing is the meaning a video game - as a culture product - may have on the shaping and consolidation of a certain iconography. For the case of the Second World War, Venegas Ramos' contribution is quite interesting. He studies the various productions about it and concludes that its aesthetics, taken

29. Montero Málaga, Alicia Inés. “Identidad e identidades: la identidad política en la historia urbana medieval. Balance historiográfico y perspectivas de análisis". Estudios Medievales Hispánicos, 1 (2012): 123. 30. Lacasa, Pilar, Los videojuegos...: 29.

31. Sauquillo Mateo, Piedad, Ros Ros, Concepción and Bellver Moreno, $\mathrm{M}^{\mathrm{a}}$ Carmen. “El rol de género en los videojuegos". Revista Electrónica Teoría de la Educación. Educación y Cultura en la Sociedad de la Información, 9-3 (2008): 130-149. Márquez, Israel. “Género y videojuegos. Roles, estereotipos y usos". Telos. Cuadernos de Comunicación e Innovación, 96 (2013): 106-114. <https://telos.fundaciontelefonica.com/ archivo/numero096/roles-estereotipos-y-usos/>. Tur Ibáñez, Diego. “La evolución de la imagen de la mujer en los videojuegos". De-construyendo identidades: la imagen de la mujer desde la modernidad, Ester Alba Pagán, Beatriz Ginés Fuster; Luis Pérez Ochando, coords. Valencia: Universitat de València, 2016: 301-320. Belmonte Ávila, Juan Francisco. Corporeidad, identidad y cultura digital: género y sexualidad en videojuegos. Murcia: Universidad de Murcia (PhD Dissertation), 2015. <https://digitum.um.es/digitum/ handle/10201/45560>. López Clemente, Vicente. “La supuesta desaparición del cuerpo: identidad, sospechas y variaciones en los videojuegos LGBTI+". Bajo palabra. Revista de Filosofía, 16, 2a época (2017): 127-137. García Marín, Jorge; Gómez Vázquez, Ma Begoña. “Identidades de género en los videojuegos a través del relato universitario". Crisis y cambio. Propuestas desde la Sociología: actas del XI Congreso Español de Sociología, Heriberto Cairo Carou, Lucila Finkel Morgenstern, coords. vol, 1. Madrid: Universidad Complutense de Madrid, 2014: 1.424-1.437. González Sánchez, Jorge. "Videojuegos queer e identidad gaymer: un fenómeno disruptivo en el mundo videolúdico". Caracteres, 7-1 (2018): 360-388. Cortés Picazo, Luis Claudio. “Transgresión de las identidades tradicionales de género mediante la representación gráfica de mujeres protagonistas para videojuegos desarrollada por niños y niñas". Arte, individuo y sociedad, 28-3 (2016): 459-473. 
from the cinematic language, determines an "American" memory of the war. ${ }^{32}$ Consequently, we are dealing with the response of locals and foreigners to what appears in any historical video game, since that emotional repercussion has a lot to do with that identitary and identifying process. On configuring the final product, the contents used by the developer must be added to that issue, whether they are graphic or text resources. We should have clearly defined ideas about this, either if they are due to specific research which are the product of real advice or if they are starting points which are the result of an iconographic combination supported on a truthful or legendary basis. That "trunk of images", which can be defined as cultural heritage, is used by developers to present a picture where users will want to operate, particularly if it is a historical video game. In order to achieve that, it is almost sure that the developer will resort to graphic elements which can be recognised by the video gamer. Thus, they are drawn as the first step of identitary definition, since there is a need for a mutual communicative understanding, in which sender and receiver identify the background of the message. I shall come back to this issue below, but I want to advance here that a clear example could be the appearance of the "Spanish" faction in diverse titles set in the late Middle Ages, when the specialists or those slightly initiated into the knowledge of the Spanish medieval period know that it was only due to a cultural and geographical referent recognisable by the "non-Spaniards", that is, by those Europeans who lived outside of the Iberian Peninsula. ${ }^{33}$ For example, in the original of Medieval II: Total War (The Creative Assembly, 2006) appears that faction of Spain with the weaponry of Castile, where Castilian and Aragonese people are brought together, and, as a counterpoint, in the first title of the series Medieval: Total War, marketed in 2002 now by Activision, not by Sega — as it has been later in all the other productions of the British studio- we do see Castile, Navarre and Aragon; in the case of Castile, with the conformation of Castile itself and León; and, in the case of the Aragonese crown, with the Catalonian counties under the same political dominion. There already appeared in Castle II: Siege and Conquest (Quicksilver Software, 1992) a series of plausible factions - Aragon, Valois, Anjou, Albion and Burgundy (sic) - in the framework of a sturggle for the investment of the French king by the pope in the 14th century. Crusader Kings (Paradox, in the three titles published so far), Plebby Quest. The Crusades (PiedPipers Team, 2020), General $\theta$ Rulers (Hamsters Gaming, 2019, in this case León and Castile are separated, as the game starts in 1207), Age

32. Venegas Ramos, Alberto. "Entre el cine y el videojuego: ética y estética en las producciones sobre la II Guerra Mundial". Videojuegos e Historia: entre el ocio y la cultura, Juan Francisco Jiménez, Gerardo Rodríguez, coords. Murcia: Editum, 2018: 87-105. See also in a more general way and by the same author: "El videojuego como forma de memoria estética", Pasado y Memoria. Revista de Historia Contemporánea, 20 (2020): 277-301.

33. Going into this never-ending debate would start a path which would take me away from the main objective of this study, but we must not forget that it is an issue discussed mainly over the last two centuries, and there are interesting pages written by all sorts of thinkers. The most recent ones are the reflections we find in the essay by Fernando García de Cortázar. Y cuando digo España. Todo lo que hay que saber. Madrid: Arzalia, 2020. Anyway, few subjects cause so much controversy as the definition of the concept "Spain". See note 78. 
of History II (Eukasz Jakowski, 2018) and Evil Bank Manager (Hamsters Gaming, 2018) follow the most truthful historical script, whereas the followers of the Total War saga have had to await the mods in order to find something more specific and according to the historical reality. I shall mention this phenomenon on several occasions throughout this study. So, what is appropriate now is to explain what a mod is and why it is important for the purpose of this article. In a simple way, it is a complement added to the original game, carried out by private initiative, intending to meet a specific aspect of the video game for a group of gamers. Therefore, the possibilities are endless and the potential to achieve truthfulness in some titles is enormous.

The aim of this article is none other than to answer the three questions posed. In the first place, how those identitary referents appear in a video game; the second, why people want to play some specific game; and the third, the reason why we choose a colour, a faction or a nation when playing focused, obviously, on the setting of the video game. I shall focus on those set in the medieval period, since they are the best samples to analyse the whole process. ${ }^{34}$ The key is to be found in a more general process, where the weighing of the Middle Ages in the 19th century Romantic period and the ideological developments of the concepts "nation", "region" and "locality" have a lot to do. However, I shall resort to other titles of video games which have a different setting or historical background if an occasion demands it. There is a clear difference in those that recuperate the battefields of the 20th century, above all those of the Second World ar and even the Cold War -including Vietnam-, although it is also interesting to recuperate some productions about the Modern Age and even about Antiquity. It is not a question of creating an exhaustive list of productions on the issue in order to make a ludography. I insist that the aim of the article is a different one. Let us not forget that the analysis of the identitary process in historical video games is the basis of this work. Possibly I may occasionally differ from some assertions just because of the preconceived positioning about a video game, about certain historical processes and particularly about some personages or events. Another ultimate objective of this study is to generate that debate. Thus, the result will be to create an analytical basis that sets the works on video games and History in a decent and legitimate place within the framework of Humanities.

\footnotetext{
34. I am answering the question posed by Iradiel Murugarren a few years ago. He stated that the identity issue "haya acaparado la atención no solo de buena parte de los estudios científicos actuales sino también de la opinión pública con un crecimiento impresionante de intereses académicos y mediáticos. En la actualidad, una fiebre de análisis de identidades recorre nuestro medievalismo peninsular y no hay congreso, seminario o ciclo de conferencias que no contenga en su enunciado este concepto convertido en una fórmula inofensiva y contradictoria, de escasa capacidad explicativa o heurística y válida para casi todo". Iradiel Murugarren, Paulino. "Al final de mucho. Conclusiones sobre identidades urbanas e historia medieval". Identidades urbanas. Corona de Aragón-Italia. Redes económicas, estructuras institucionales, funciones políticas (siglos XIV-XV), Paulino Iradiel, Germán Navarro, David Igual, Concepción Villanueva, coords. Zaragoza: Prensas de la Universidad de Zaragoza, 2016: 329.
} 


\section{The Development of Video Games and the Necessary Actors - Factions}

As pointed out above, video games are essentially interactive: the gamer is an essential part in their execution. It is true that the script, the developer of their software, their infographic makers and even their distributor contribute to configurate the product result. But the end is set up by the video gamer: their actions mark the evolution of what "happens" in the game. The difference with the other media of cultural expression is that the spectator-reader behaves passively in the latter when third persons appear. In the world of video games, the active part of the person gaming clearly defines the consequence. I value these words in the sense that it is a fact that whoever has not gamed will not understand its idiosyncrasy. It is a clear invitation to those positioning themselves as contrary to experimenting with leading a host in a strategy game, with a virtual personage or, simply, with piloting a plane in the recent Microsoft Flight Simulator (Asobo Studio, 2020), an impressive visual spectacle - an invitation to do it, even if it is in a brief way. It is not a question of playing Candy Crash, Pac-Man or Tetris, which are also video games, but of getting to know that this medium has evolved so much and that it is not only like watching what one of our nephews is playing. ${ }^{35}$

I initiated this line of research a few years ago, a contribution to this review, with an analysis of the impact this medium started to have ostensibly on the knowledge of the Middle Ages by avarage users, those who did not have a good knowledge of the period and everything they began to learn about it came to them through the video games available in the market at the time ${ }^{36}$. The picture has greatly changed since then: over the last decade new products have been marketed, titles that have produced an enormous impact, like Kingdom Come: Deliverance (Warhorse Studios, 2018), A plague tale: Innocence (Asobo Studio, 2019) and the most recent one, Crusader Kings III (Paradox, 2020), just to cite a few examples. Others have been revitalised, like Age of Empires II, after being remastered. ${ }^{37}$ Obviously, I am not going into the development of productions carried out as intended to value

\footnotetext{
35. In the 35th letter in José Cadalso's Cartas Marruecas there is an allusion to that "nephew", an expert in the latest cutting-edge issues, which at the time consisted of the flow of lexical loans coming from French. We could transport that example to the present day. I say that because "identity" is "threatened" by a new language which can lose its idiosyncrasy; it is a fact that creates confusion, if not fear, on most occasions, then and now. (Cadalso, José. Cartas Marruecas. Biblioteca virtual Miguel de Cervantes. 28 enero 2021 <http://www.cervantesvirtual.com/obra-visor/cartas-marruecas--0/html/p0000002.htm\#I_37_>).

36. Jiménez Alcázar, Juan Francisco. “Video games and the Middle Ages”, Imago Temporis, 3 (2009): 311 365. I updated the text a few years later under the title "Videojuegos y Edad Media 2.0", included in the monography De la Edad de los Imperios a la Guerra Total: Medievo y videojuegos, Murcia: Compobell, 2016: 11-73. <https://historiayvideojuegos.com/wp-content/uploads/attachments/47.pdf>.

37. Marketed as the second game of the saga in 1999, and developed by Microsoft Ensemble Studios, Age of Empires II was edited in high definition in its remastered version, where the various DLC or expansions have been included under the development of Forgotten Empires, Tantalus Media and Wicked Witch, and distributed by the Microsoft Store. In late January 2021, the latest DLC was commercialised, "Lords of the West" (Forgotten Empires, Wicked Witch Software and Tantalus Media, 2021), with three new campaigns: Edward I of England, the dukes of Burgundy in the 15th century, and the Normans in Sicily in the 11 th century.
} 
their heritage, educational or virtual reality aspects, like the effect of disembarking goods in the port of Bruges in the 14th century with Historium VR-Relive the history of Bruges (Sevenedge Interactive Media, 2016). Today, as then, I feel that the issue needs addressing, but from a more specific perspective, as the stage of mentioning that there are video games whose script is set in the medieval period or in any other time is over. I think that the maturity of the research line dealing with the impact of a video game upon the historical discipline is already consolidated, however not in order to write about History but to take referents concerning memory, various approaches or asymmetric studies in which we will understand the latter as those basing their starting points from positions having a different background. As a result, we should not return to justify the reason for a study on video games. ${ }^{38}$

The first factor to draw the attention to is the original idea: why is a video game on the Middle Ages created and where is it set? It is obvious that the idealised image of the medieval period suggests the creation of dream worlds and fictional civilisations gestated in the minds of their creators, where the contributions to tradition are unquestionable references from chivalry books to the "Western Lands" by G. R. R. Martin. We take a firm step through the contribution of the Romantic movement and Sir Walter Scott's novels as well as Tolkien's and Lewis's vigorous works. It is obvious that if money, time and effort are invested on generating this kind of productions, it is because there is a demand amongst users, a great number of people who do not limit themselves to a particular space: it is a global phenomenon, where millions of people come to play specific titles, even paying monthly fees. More than a market niche, it is a market in itself. World of Warcraft is a good example of what has been said, not to mention Fornite, which has nothing to do with a legendary medieval background. Nothing new is being revealed, but this is worth remembering: it is not a phenomenon restricted to "strange people", but a medium extensively established in our society and particularly intensive in some countries. ${ }^{39}$

\footnotetext{
38. Years ago, James Newman established the reason why video games should be analysed, so I am not going to insist on it: “¿Por qué estudiar los videojuegos?”, in Daniel Aranda and Jordi Sánchez-Navarro (eds.), Aprovecha el tiempo y juega. Algunas claves para entender los videojuegos, Barcelona: Ed. UOC, 2009: 61-105. This contains the first two chapters of his monography Videogames, London: Routledge, 2013 (1st ed. 2004): 61-105.

39. This note is rather a spoiler. The Korean case is worth mentioning. In 2018 was the release of a k-drama (or dorama, TV series or South Korean soap) entitled Memories of the Alhambra, which was included in the Netflix repertoire in 2019. Starring Hyun Bin and Park Shin-hye, and produced by Studio Dragon, it is a romantic fantasy comedy whose story is based on the development of an augmented reality game set in the Nazari kingdom, where at first you fight warriors from Granada and Aragon that is what it seems - to end up against ninjas and armed commandos. The title resumes the work by maestro Tárrega, which is heard throughout and is played by a virtual female guitarist, who is inspired by the character of the game creator's sister (always in the fiction). Most interesting is the reference we can locate, a few months later, in another k-drama, Crash Landing on you (Dragon Studio, 2020, also in the Netflix inventory), when the same main character, Hyun Bin, who embodies a North Korean Officer who infiltrates into South Korea, is playing a video game (with the "Tomato Grower" avatar). Then the same soundtrack can be heard, a clear allusion to the first teleseries and a clear message to the viwer. I would like to insist on the deep rooting of the video game phenomenon in the Korean society, as that script would not have been possible without the previous knowledge of what that medium presupposes on the part of the viewer.
} 
Therefore, it is obvious that the products consumed are those generated. There is room for the Middle Ages in the ample cultural offer including the historical past demanded by a global society. Video games are prepared to meet it in their own way, similarly to the manner historical novels, cinema, television and comics do it, occasionally with a clear transmedia framework. Once that primary decision has been made, that of the period and the context, besides the well-known gender which has been chosen - strategy in real time, in turns, arcade, graphic adventure, etc.- all the necessary gear is launched to market a video game. The main actors are defined: factions, nations, characters, etc, which will respond according to the developer's profile - more historicist in style or more fanciful. Following that, the receiver of the production is to be present - the video gamer. When the game is being made, its users are always being thought about. On choosing a title, a gamer makes a lot of decisions: on the one hand, what kind of video game they want, as it will condition how they are going to game. A strategy production is not played in the same way as an action production. On the other hand, whether they want a historical one or not. This does not exclude other titles, as a gamer's tastes, on the whole, are complementary with various genders, although they may have some preferences. The medium they choose is also important. A few years ago it was thought that PC games were destined to disappear, but nothing could be further from the truth. The console setting, which contributed to widespread the medium, has not stopped growing, with the development of hardware generations every seven or eight years. The companies use diverse strategies to introduce their titles in the market; and we can find certain video games commercialised on the various platforms or on some exclusively. In this sense, it is interesting to state the role of the online game distribution. A few years ago, the retail sale of the titles for PCs was the usual system, but the development of online platforms has contributed to the access to those games: Steam, Gog, the Ubisoft (Uplay) themselves, EA (Origin), Kalypso, Microsoft on its virtual shop, or Sony and Nintendo..., besides the open possibilities on the subscription channels in some of them, like Origin Access, Geforce Now, Game Pass o Google Stadia (with all the differences that define them, including the catalogue of the titles in each one of them, or the method to access them).

This scenario, which I have considered it is important to state, helps video gamers to obtain an easy access to these productions, on line with what watching certain kinds of films on the cable television platforms can be today, from Netflix, Rakuten, HBO, Amazon Prime or Apple TV to Filmin. Therefore, a video gamer's decisionmaking capacity already starts from a wide range of possibilities which will condition their definitive choice.

On taking that decision a gamer already starts from a premise - that of knowing that the video game counts on him or her from the beginning. The distribution companies have always emphasised that factor determining the medium, as has been pointed out. Marketing and advertising have always resorted to the concept of "you" as something essential. It was not strange to find references to the user's direct participation on the covers and back covers of the physical games; I would even say that it was the norm. Now we can find these references in the text explaining the 
platforms or in the press releases, which the specialised press extracts its information from. Here is a clear example: on the back cover of Crusader Kings (2004), the first one to open the saga of Paradox, we can read:

You are the leader of a glorious dynasty. Amass prestige and piety and the world will pronounce your name with respect. Increase the greatness of your lands and treasures; build cathedrals and castles and fight the bandits and the vassals who want to go away from you. Issue laws and impose taxes, interact with hundreds of courtiers and noblemen (...)

Will you be able to organise the defence of your lands while you recruit a great army? Will you be able to bring together other kings and the Pope under your leadership to free the Holy Land? Do you have all the requirements to become a crusader king?

It goes on with indications and specifications of what one can find in a video game. In general, the second one in the saga (2014) reproduces almost the same direct messages, whereas the third one (2020) nearly eliminates that resource. I think that the distributors did not consider it necessary, as there is no need to insist on something that is completely assumed by a potential buyer.

The faction, and the concept of "nation" as synonymous with it in this framework, is incorporated to historical video games in which their script is developed in past ages, where we will find from Sumerians, Egyptians and Greeks - and their diverse city-states - to the Romans, according to each period. It is those who start to resort to lower Imperial and late Antique stages the ones that initiate an inclusion process in the game of factions-nations, which are those that ended up by configuring the national background attached to a people and, finally, to a territory.

This is an interesting precision as those set in the Prehistory, like Dawn of Man (Madruga Works, 2019) or Ancient Cities (2020), do not show the possibility of choosing a faction; if anything, the primary location from which initiate the game. In those based on the periods after the year One Thousand, like XIII Century, Death or Glory (1c Company, $2008^{40}$ ), we start to glimpse people-nations which derive into those we know at present: English, French, German, Spanish. Regardless of the moment the game refers to they beguin to appear amongst the options available to the user, like Age of Empires II: the Age of Kings (Ensemble Studios, 1999) and its later expansions. In fact, the architecture visible on the interface resorts to images and icons which are prototypical of those nations. For example, in the Spanish faction the Sevillian Torre del Oro is the wonder that can be built, just as the gothic cathedral of Chartres for the French one ${ }^{41}$ or Saint Sophia for the Bizantines. The objective, then, is to use a

\footnotetext{
40. Republished in Spain by FX Interactive in 2011 under the title Real Warfare. Grandes batallas medievales. Anthology.

41. The establishment of the Gothic art, identified from its very genesis as French, encountered some opposition just for this assimilation. "Se opusieron tenaces resistencias a su expansión. Se debían a la política, pues los soberanos rivales del rey de Francia intentaban apelara otras fórmulas estéticas para distinguirse. Se debían también al substrato cultural; cada país conservaba maneras de sentir, de pensar y de creer, que levantaban pantallas más o menos sólidas ante la irrupción del arte gótico". Duby, Georges. Europa en la Edad Media. Barcelona: Paidós, 2006: 123.
} 
well recognised iconography which identifies it with its architectural achievements another further way to obtaain that user's immersion into the civilisation chosen. It is important to point out that we are dealing with decisions taken by the developers, and they start from preconceived ideas of what they think to be significant constructions in that civilisation. That is an issue certainly worth debating, if not questionable. Let us not forget that the uniformity in the pictures set in the past also generates identity, as they are recognisable by the video gamer, who considers them characteristic of their cultural background and iconographic structure.$^{42}$ It is a resource similar to that of language, since it is included as an immersive factor to involve the gamer in the space context of the video game, and generates that identification. ${ }^{43}$ That is the case of the various expressions in Age of Empires II, of those heard in the diverse Assassin's Creed, and even in the use of toponyms, like Total War Saga: Thrones of Britannia, where appear the old Saxon names of the various towns.

The "faction" factor is essential in the set of a videogame, since it is based on the idiosyncrasy of the medium. We again encounter decision, the choice the user has to face. It ends as a "plus" added to the specific title, as the chances the user has when choosing who to play with, or with which piece, faction, colour or nation increase the specific weighting of the video game - something that is not exclusive to this medium either. ${ }^{44}$ Obviously, I am referring to those productions where those choices can be found. In the settings of the Spanish Civil War, like Battle for Spain (Headquarter S.L., 2019), España 1936 (Ageod, 2015), Sombras de Guerra. La Guerra Civil Española (Legend, 2007), or in those of the American Civil War, which are more numerous, (American Conquest. Divided Nation-Cdv, 2005-, Battleplan: American Civil War - The Mustard Corporation, 2014-, Civil War II -Ageod, 2013 - Gettysburg. The Tide Turns — Shenandoah Studio, 2017-, Grand Tactician: The Civil War. 1861-1865 —Oliver Kerppelmüller, 2020_ Ironclads: American Civil War Totem Games, 2009, the second in the series, released in 2015-, Ironclads: High Seas -Totem Games, 2009-, North $\theta$ South - Infogrames, 1989-, Railroad Corporation, in a specific DLC: Civil War —Corbie Games, 2019-, Take Command. Second Manasas -Paradox, 2006-, Ultimate General: Gettysburg —Game-Labs, 2014 — and Ultimate General: Civil War -2017, Victory o Glory: The American Civil War — Forced March Games, Electric Games, 2020_, War of Rights —Campfire Games, 2018-, etc.), the choice is limited to two options. That is seen in the eyes of many players as a Manichaean positioning, a fact that we must not neglect.

\footnotetext{
42. Venegas Ramos, Alberto. “Retrolugares, definición, formación y repetición de lugares, escenarios y escenas imaginados del pasado en la cultura popular y el videojuego". Revista de Historiografía, 28 (2018): 323-346. Also by this author, "Ver y sentir el ayer. La reconstrucción fotorrealista del pasado en el videojuego histórico". e-Tramas, 5 (2020). <http://e-tramas.fi.mdp.edu.ar/index.php/e-tramas/article/ view/47>.

43. About this issue, see Abad Merino, Mercedes; Jiménez Alcázar, Juan Francisco. “Recrear la lengua de otro tiempo. Ambientación lingüística diacrónica en la televisión y los videojuegos". Videojuegos e Historia: entre el ocio y la cultura, Juan Francisco Jiménez, Gerardo Rodríguez, coords. Murcia: Editum, 2018: 9-33. 44. Why do we choose green or blue in parcheesi? Or why do we choose white or black in chess? Do we alternate or, if we can, do we opt always for the same colour? It is the case of the Monopoly game, where the preference for a certain figure in the game is normal.
} 


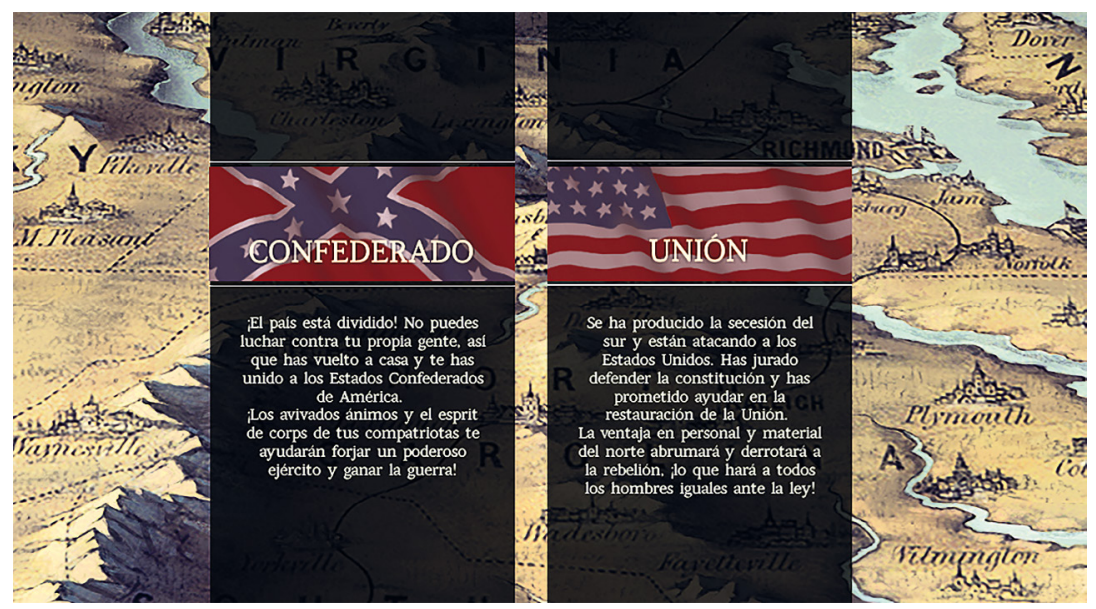

Illustration 1. Ultimate General: CiVil War (Game-Labs, 2017).

Although it may be only because it is more likeable, the user will always have a preference for one of the two sides, where, amongst many other causes, a romantic or adventurous cause or any other possible ideological reasons may not be hidden. But if we discard those moments of confrontation between two clearly defined factions, in the video games inspired by more general stages a positive issue seen by the user is brought about and is the fact of finding the possibility of choosing amongst historical factions. For example, in XIII Century: Blood of Europe (1c Company, 2010), one can choose among 24 nations (sic). We can see that, in the advertising strategies of the game distributors, the increase of the factions available is specifically pointed out, and, on many occasions, they are specific DLC. In the case of the Late Antique and High Medieval period, the historicity of some productions allows us to diversify those options, as there exists the possibility of choosing amongst various cultures and a specific faction within each of them. For example, the culture of the "barbarian kingdoms" is found in the case of Total War: Attila (The Creative Assembly, 2015), a video game focused on the great barbarian invasions of Europe. Once we have chosen that option, we can, in turn, choose between the Francs and the Saxons. It goes on with the line-up dealing with the culture of the "Great nomads" (we can choose amongst the Ostrogoths, the Alans, the Vandals and the Visigoths), of the "Nomadic tribes" (in this case the gamer can only choose the Huns), of the "Roman Empire" (the Western Roman Empire and the Eastern one), of the Oriental Empires (only the Sassanides appear) and the culture of the "Nordics (Jutes, Danes and Gautas). The subsequent DLC include more factions, which complete the previous ones: the White Huns (known like that by the Byzantines and Hephthalites by the ancient Greeks, Ytas by the Chinese and Shevetahunas by the Indians); the Sueves (among the great nomads); the Longobards, Burgundians and Alamans (among the 
barbarian kindoms); and there rise thre more great grups: "Kindoms of the Desert" (Aksum, Lajmid, Tanukhid, Himyar and Garamantes), "Slavs" (Sclavonians, which was the name the Byzantines gave to the Slavic peoples, as well as the Anteans and the Venedians), and the "Celts" (including the Ebdans, the Picts and the Caledonians $)^{45}$. Certainly the users' complaints because of the lack of choices, each one with their pecularities and interest, are solved with the mod phenomenon.

If anything, to me as a medievalist the expansion "Charlemagne" is more significant. It was marketed in 2016 as a complement to the original game. It had the factions of Charlemagne's kingdom, of the kindom of Asturias, of the Avars, of the Cordovan Emirate, of the kingdom of the Danes, that of the Longobards, that of Mercia; and the Westphalia territory.

We consider it a wise choice that the developers included historical personages as leaders of the various factions, like Charlemagne himself, Widukind, Offa, Abdelrahman and Aurelius.

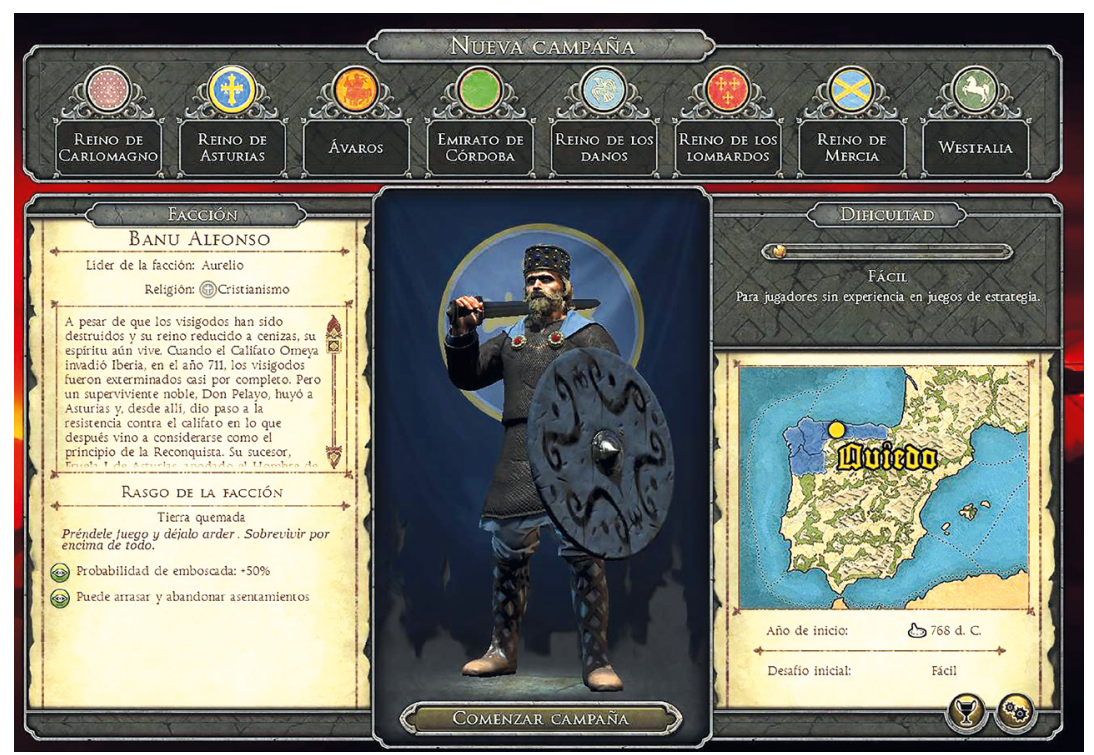

Illustration 2. Faction of the kingdom of Asturias. Total War: Attila. Expansion Charlemagne (The Creative Assembly, 2016).

45. In Total War Wiki (<https://totalwar.fandom.com/es/wiki/Wiki_Total_War>) we can locate each one of the factions and their references among the classic authors, as well as in which of the DLC they are to be found. The fan phenomenon is certainly spectacular, and the historians' role is essential in this development; therefore we should not elude it. 
This rather personal comment is the best proof that video gamers try to be active even when they are about to choose what they are going to play. It is in this case where that "identification" with what is happening in the video game can be best observed and is worth pointing out. If the gamer is skilful enough, it is possible to repopulate León or Valladolid in that vast "no-man's land" gestated in the 8th century in the Duero River basin. The medievalist gamer's role is visible here, but it is more so if the gamer is a native of any of these places.

This usually happens in this kind of strategy games. Without leaving the world of Total War, in Total War Saga: Thrones of Britannia (2018), and with the same outline, in this title set in the year 878 A.D., the year of the battle of Edington, we have the option of playing with the English kingdoms of Mercia and Wessex (in the latter case, introducing the leader Alfred the Great); with the Welsh kingdoms of Gwynedd and Strat Clut and the Gaelic ones of Circinn and Mide; and with the Great Viking Army (presenting the territories of East Anglia and Northumbria); as well as with the Viking Sea Kings (Dublin and Sudreyar). Through previous knowledge of the British history of this High Medieval time, a video gamer can enjoy a certain preference; more if they have got to know any of the personages in a TV series (Vikings or The Last Kingdom). I suppose it is more likely that they have seen these than viewed the film Alfred the Great (dir. Cl. Donner, 1969) or read any of the novels by Bernard Cornwell. Certainly that is precisely the way followed by that user in the video game and the reason why we historians should be more commited not to leave without a guide those who have the knowledge but not qualified knowledge.

An aspect we must bear in mind is that not all the factions appearing in these games, usually strategy games, are playable by the user. They participate with the guide of the IA and are an essential part of their development; that is why the degree of difficulty chosen conditions the evolution of the game. It is not unusual that, as the game in question advances, the dynamics eliminates some of these factions. The user's problem arises when the eliminated one is their faction. And such is the game: winning or losing according to the sequence of good or bad decisions. But the interesting thing is the emotion and the decision-making factors so that the user chooses one of those factions and not the others. Those that are not playable can generate dissatisfaction to the gamer. That is why the mod phenomenon is essential: an issue that has already been raised but to which I shall return below. ${ }^{46}$ This kind of decisions is not exclusive in

46. These "secondary nations" in the game can become very numerous. In Napoleon: Total War (The Creative Assembly, 2010), those playable are France, Austria, Great Britain, Prussia, Russia, the Otoman Empire and Spain; the non playable ones: Danemark, Sweden, Republic of Batavia, Portugal, Swiss Confederation, Bavaria, Baden-Würtemberg, Hesse, Oldenburg, Mecklenburg, Saxony, Kingdom of Italy, Kingdom of Naples, Kingdom of Sicily, Kingdom of Sardinia, Papal States; for the Italian campaign there are also the following: Piedmont-Sardinia, Tuscany, Lucca and Venice; and in the Egyptian one, the Mamluks. In the Spanish campaign Portugal can be playable in the multiplayer mode. In this game, and due to its evolution, new factions can arise as the result of rebelions, besides the rebels who are always present in all the titles of Total War: Italy, which replaces the Kingdom of Italy, that of Naples, that of Sicily or the Papal States; the Low Countries, which does the same with the Republic of Batavia, Hannover, Westphalia, Hungary, Romania, Greece, Khanate of Crimea, Curland, Poland, Norway, Belgium, Scotland, Ireland, Britanny, Catalonia; and, in the Italian campaign, Parma, Genoa, Milan, Modena and Trento. 
the dynamics of video games, both because of the experimentation itself and because of other kinds of purposes. In my case I would rather play with the widest range of possibilities to check what each title offers. That is never the interest of the developers who have implemented it. We must not forget the fact of choosing one faction and not another, as it offers a lot of information from the user. I insist on the "emotion" factor, since it occasionally becomes an excluding issue. ${ }^{47}$

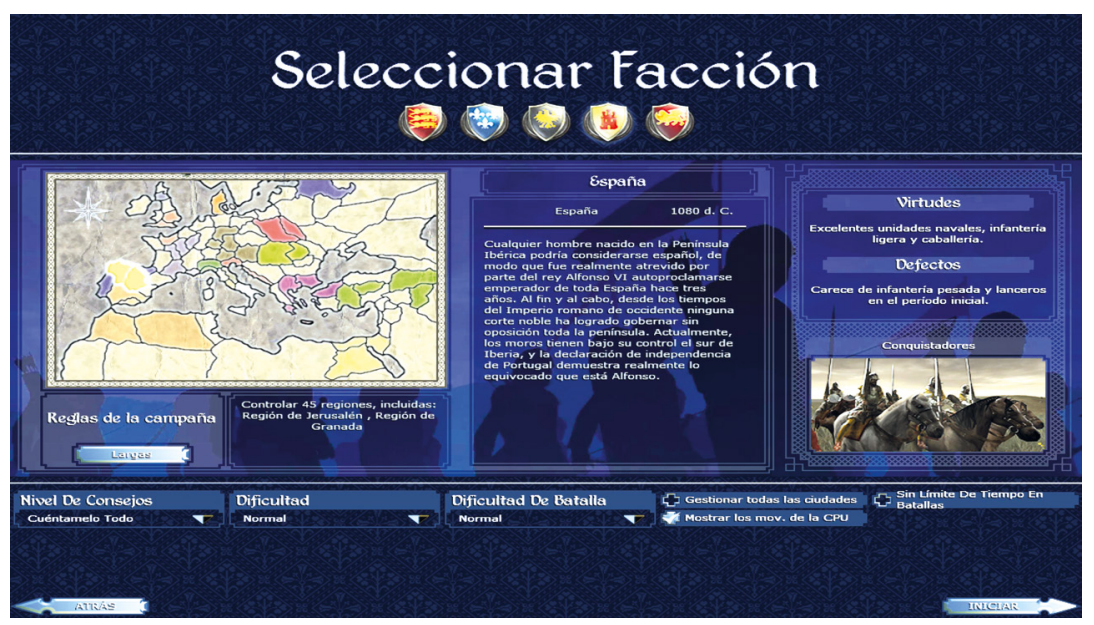

Illustration 3. Factions of Medieval II: Total War (The Creative Assembly, 2006).

Historical development also goes together with videogames. In the already mentioned Medieval II: Total War, which starts up in the European 11 th century (1080 AD), the factions are already defined by the new monarchies which will result in the future late medieval and modern states. In this title, for example, we find England, already with the arms of the Plantagenets and their leopards or lions on a red (gules) background; France and its yellow (or) fleurs-de-lis on a blue (azure) background; the Holy Roman Empire, which, although it does not state that it is the German one, uses the emperial eagle as its identifying coat of arms; Venice and its naval pavilion, the winged lion of St.

47. At the International Medieval Meeting in Lleida in 2014, I carried out an interesting demonstration among the presents there. I advanced something of what is shown in this study. I asked the participants, most of them football fans, and particularly F.C. Barcelona fans, if they ould wever choose Real Madrid at a game of Pro Evolution Soccer or FIFA. They answered, almost in unison, that they would never, ever do that. I am sure that in all similar contexts the answer would be the same. In the Spanish case, no Sevilla F.C. fan would choose Real Betis, and viceversa. And so, very many examples: At. Bilbao-Real Sociedad, Barcelona-Espanyol, etc. The same in Italy, England, Germany, Argentina... I cannot imagine a Boca fan choosing River, never, unless intending it loses and by a landslide. 
Mark on red (gules) background — the civil one was on sky blue-; and Spain, with a coat of arms dominated by a red (gules) castle against a yellow (or) background.

The rest of the factions that appear in the game are part of the multiple reality of the territories and powers of the period, but they are not playable. Anyway, the remarkable thing is the use of the coats of arms as identifiers of the factions. If the 12th century is the period when these identifying elements for lineages and, consequently, for the territories they led, the problem is not this anacronism but the fact that the developer's intervention has a repercussion, on the one hand, on the most visible definition of the faction, and, on the other, on its denomination. The "Spanish" case is the most paradigmatic of them all, as the political concept did not exist at the time, although the greographical and cultural one did exist, as mentioned above, and the coat of arms, which could be identified as that of Castile, also has its colours exchanged, besides the fact that it is originally from Alfonso VIII's reign. ${ }^{48}$ The question then arises of the developer's interest in using this kind of symbols and denomination which do not correspond to the historical reality. We can suspect that the objective of these productions is to cover a generic demand, without considering any market niches besides the one that is formalised by the user of the historical strategy video games. It is not possible to play Navarre as a faction and it can only be found among those used by the IA to establish a playability designed by the development team to achieve the most correct setting, above all in the strategy video games, like in those cited from the Total War series.

In those that base their development on the final periods of the Middle Ages, especially after the 13th century, the factions correspond to the great nations already configured by that time. Like in the case of "Spain" or the "Spaniards", something similar happens with the "Italians" in Medieval Total War. These most correct identifications will only be resolved by the users' specific action through the mod phenomenon.

Nevertheless, there are titles that can meet that demand. That is the case of Crusader Kings II (Paradox, 2013). In its guide we can read:

You can control the destiny of any of hundreds of historical dynasties as they seek to rise from the chaos of the Dark Ages and dominate the politics of Medieval Europe ${ }^{49}$.

However, this particular title is not based on nations but on dynasties. That is why the question varies, although not very much, as the territorial adscription to what would be modern monarchies later produces the same result:

You will not be able to "conquer the world", bound as you are to the feudal system, but you can make your power and authority felt in any given generation. You see, unlike any other Paradox game, it is personal this time. It is your family, your dynasty, who you will trace and

\footnotetext{
48. De Francisco Olmos, José María. "La emblemática castellana de Alfonso VIII". Anales de la Real Academia Matritense de Heráldica y Genealogía, 17 (2014): 215-249.

49. Manual Crusader Kings II, p. 4. Paradox Interactive. 28 January 2021 <https://cdn.akamai.steamstatic. com/steam/apps/203770/manuals/PDX7605US_CK\%20II_Onlinemanual.pdf?t=1589809595>.
} 
lead through the centuries as they seek to claw their way to the top of the feudal pyramid and stake their claim as Crusader Kings.

This series, Crusader Kings, identifies faction and lineage, and so there does not exist that emotional decision when making the choice, or at least it is not usual. The simple reason is that there are no causes generating the identitary process, unless it is the empathy with a character. On the back cover of the first game corresponding to the back cover of the first title, we can read: "Take control of one of the great Christian dynasties in Europe and try to create a great nation under your command. You will be able to play with dynasties such as those of Castile, Aragon, León, Navarre, Catalonia, Byzantium, Normandy, etc." This fact is repeated in the last one, the third, also with the following text in the same place as the one cited above: "Choose from various kingdoms, lead your dynasty throughout the centuries and live the drama and ostentation of the Middle Ages". In the same way, and placed below the illustration of Diplomacy and war, we can read this: "Extend the range of your power and protect, at the same time, the future of your dynasty". ${ }^{50}$

At this point, we must discuss the idea we have, in general, of what medieval is and also its spacial and temporal boundaries. There is no doubt that it is a Eurocentric phenomenon, and so it is reflected in titles like those of the series mentioned Crusader Kings. Its selection and its corresponding identification with the faction selected are very well defined by someone born in Europe. But it is worth rising to the challenge of the factions presented in productions set in China and Japan. Again I am resourcing to the works by the The Creative Assembly team, especially because of the settlement and commercial success among the users all over the world, thanks to the various online-selling web portals.

In Total War: Three Kingdoms (2019), a video game set in Three Kingdom China (220-280), although it starts in $190 \mathrm{AD}$, we see twelve factions trying to hold together all the Chinese territory under a single authority. That is why the leaders play an especially important role. But it is also important because of the names and territories, which are completely unknown by an average "western" user: for example, Cao Cao, Lui Bei, Sun Jian, etc. ${ }^{51}$ The title allows us to play in a less historicist mode, which follows the script of "Romance of the Three Kingdoms". ${ }^{52}$ Its factions are very numerous; they reach the number of thirty-six if we add the vassal ones and those non playable.

\footnotetext{
50. In Italian, as it is an Italian-Spanish publication, "Espandi i tuoi domini e costruisci un futuro sicuro per la tua dinastia".

51. I consider its user as someone having a level of basic historical and cultural knowledge, or, at least, they do not correspond to a professional or a specialist in the subject.

52. Another two recent games deal with this subject: The Three Kingdoms of China (中三之家, 2019, only playable in Chinese languages) and Romance of the Three Kingdoms XIV (Koei Tecmo Games Co., Ltd., 2020), although there were others, like Dragon Throne. Battle of Red Cliffs (Object Software, Strategy First, Planeta, 2002). Strength $\theta$ Honour. Empires in the Ancient World (260 a.C.-100 d.C.) (Merscom, Magitech, 2004). It includes China as a faction, along with Rome, Egypt, Persia, Gaul and India.
} 
It is the Han dynasty's death throes; that is why it is outside of the chronological boundaries intended. But it deals with a civilisation which is far away from the West and is identified as something fictitious and comparable to those factions invented in a different type of fantasy titles. For example, nobody will doubt that Mordor, Calradia, Disembarkation of the King and Invernalia are more recognisable destinations for a western video gamer than all the list of the names and territories of Han China. But curiously enough, it will be surprisig that the invention of paper occurred in those lands and in those years, and that it counted on geniuses like Zhagn Heng, who is to be credited with the invention of the first seismograph, and with an outstanding knowledge of Astronomy. ${ }^{53}$

But we do count on a title which is more centred in the period, Total War: Shogun 2 (The Creative Assembly, 2011), where the factions are related to the various clans involved in disputes. So, for the original title, set in the stage immediately preceding that led by Oda Nobunaga, Toyotomi Hideyoshi and Tokugawa Ieyasu, we have, in the year when the game begins, 1545, the clans Chosokabe, Shimazu —which came from the Minamotos, the founders of the Kamakura Shogunate-, Hojo, Mori, Oda, Date, Takeda, Tokugawa, Uesugi, Hattori, Ikko Ikki and Otomo. ${ }^{54}$

After the end of the Ieyasu government, the Edo or Tokugawa period started, which ended with the Meiji Revolution. We find the same problem presented in the game set in ancient China earlier. The names and territories are quite strange denominations to those who have not studied the culture and have only basic knowledge. But if this epoch - the Songoku period, also called period of the Warring States-, which began after the Onin war (1467-1477) and is inserted in the Muromachi period, is already complex in itself, the Kamakura period (11851333 ) is more significant because of the "Genpei War"; we can play that in the already cited Total War: Shogun 2, specifically in the Rise of the Samurai (2013). ${ }^{55}$

53. The first European seismograph was built 1700 years later; and due to his achievements in Astronomy, a lunar crater is named after him.

54. This title goes together with another that presents the same characteristics, Oda Nobunaga's Ambition: Sphere of influence (Koei, 2013), although, in this case, it is inspired by Shiba Ryotaro's historical novels Kunitori Monogatari for the "design of the main character". Besides, it is part of a series of video games originated in various platforms since the 80s. About this matter, see Claudia Bonillo Fernández: "La literatura histórica y el videojuego. El caso de Nobunaga's Ambition: Sphere of Influence (Koei, 2013)", e-Tramas, 3 (2019): 1-19. <http://e-tramas.fi.mdp.edu.ar/index.php/e-tramas/article/view/32/25>. By the same author, "Desde la yoroi hasta los kimonos de la Corte. Los personajes de Nobunaga's Ambition: Sphere of Influence (Koei, 2013)", e-Tramas, 2 (2019): 11-50. <http://e-tramas.fi.mdp.edu.ar/index.php/etramas/article/view/17/22>. In order to get to know how this character, so significant for the Japanese people, appears in the general media, see also her work: “Oda Nobunaga en los videojuegos de Japón. Imágenes de un personaje histórico". Videojuegos e Historia: entre el ocio y la cultura, Juan Francisco Jiménez, Gerardo Rodríguez, coords. Murcia: Editum, 2018: 35-56. For the Sengoku period, see again by the same Aragonese author: "Nioh (Team Ninja, 2017), another alternative vision of the Sengoku period (1467/1477-1603)". Ocio, cultura y aprendizaje: Historia y videojuegos, Juan Francisco Jiménez, Gerardo Rodríguez and Stella Massa, coords. Murcia: Editum, 2020: 9-62.

55. A recent work, which is a general compendium of the Japanese history, addresses these processes in a generic way: Pérez Riobó, Andrés and San Emeterio Cabañes, Gonzalo. Japón en su historia. De los primeros pobladores a la era Reiwa. Gijón: Editorial Saitori, 2020. 


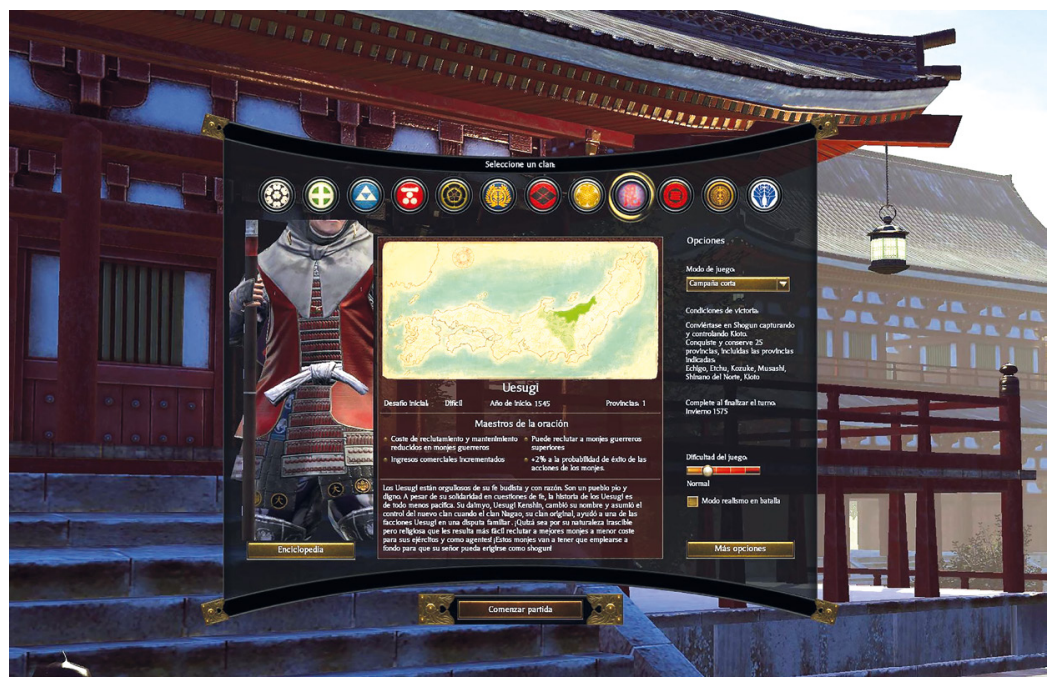

Illustration 4. Faction of the Uesugi clan. Total War: Shogun 2 (The Creative Assembly, 2011).

This civil conflict, which brought an end to the Heian Era, ${ }^{56}$ starts in 1175 in the game with the Minamoto clan and the options Kamakura Minamoto and Kiso Minamoto; with the Taira clan, Yashima Taira and Fukuhara Taira; and finally with the Fujiwara clan and the Kubota Fujiwara and Hiraizumi Fujiwara factions. There are more titles set in the Sengoku and Edo epochs, like Sengoku (Paradox Development Studio, 2011), Sengoku Jidai: Shadow of the Shogun (Byzantine Games, 2016), Shadow Tactics. Blades of the Shogun (Daedalic, 2017), and others. All of them serve as examples of what has just been said. Notwithstanding, the territories considered "western" and situated on the other side of the perspective are also something exotic. They require specific learning, as they do not embody any cultural heritage, whether specific or remote, although there are some exceptions. ${ }^{57}$

The choices available in the titles set in the Middle Ages already reflect the political situation of the Eureopean monarchies at the moment: England, France, the Hispanic Monarchy or Spain - the example of Empire: Total War (The Creative Assembly, 2009) is quite clear; there its historical use is correct after the shaping of the kingdom of Spain by Felipe V of Borbon-, Russia, Prussia, Sweden, etc., but they are usually centred in a Eurocentric idea, including the American territory. It is in the titles set after the French Revolution where the number of the factions

56. Almarza, Rubén. Breve historia del Japón feudal. Madrid: Nowtilus, 2018: 85 and following.

57. About this issue, see Guarné, Blai. "Shall we westernize? Sobre la idea de "Occidente» en el imaginario japonés contemporáneo". Japón y el mundo actual, Elena Barlés and V. David Almazán, coords. Zaragoza: Prensas Universitarias de Zaragoza, 2010: 767-819. 


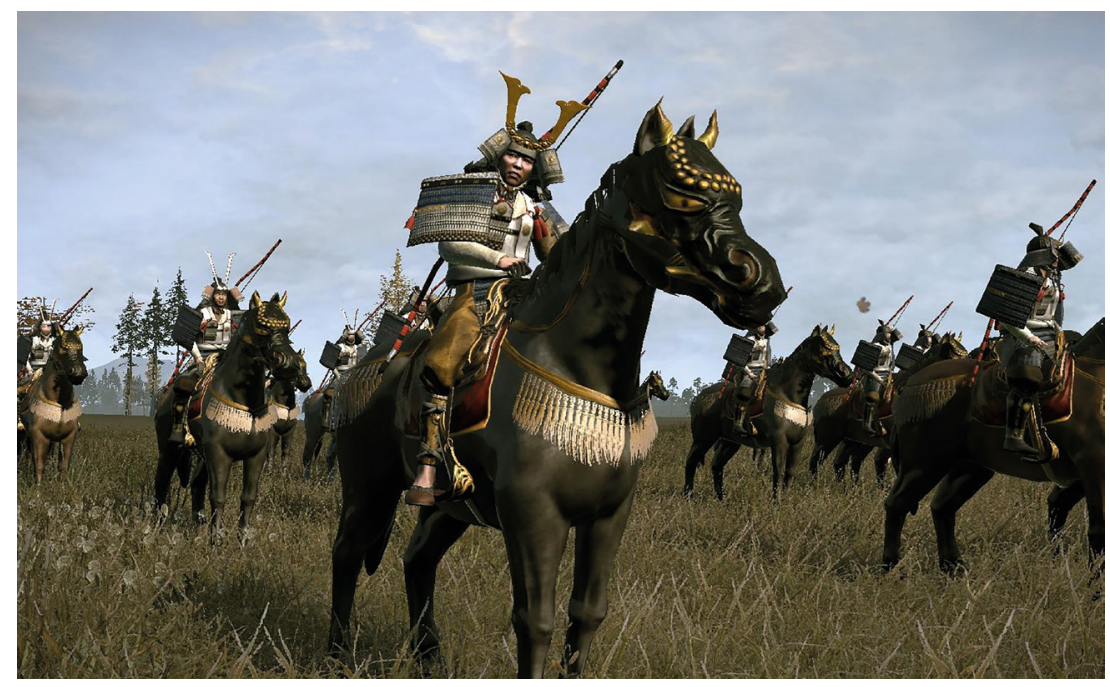

Illustration 5. Cavalry of the Kamakura Minamoto clan. Total War: Shogun 2. Expansion Rise of the Samurai Campaign (The Creative Assembly, 2013).

increases, in fair correspondence with the globalisation process unstoppably initiated then, following the European colonisation process of the world, which we now live in a vertiginous way, like, for example in Victoria II (Paradox Development Studio, 2010), where more than 200 nations can be chosen. If any, it is the reflection of the nationalist idea born under the political and social processes of the 19th century. We have the same approach for the example of what was mentioned above concerning the Japanese scenario with Total War: Shogun 2. La caída de los Samurái (The Creative Assembly, 2012). Basically it is the "Boshin War", ${ }^{58}$ which resulted in the disappearance of the political power of the Shoguns. Among the supporters of the Tokugawa Shogunate the following clans are available: Obama, Sendai, Jodai, Aizu and Nagaoka; and among the supporters of the imperial power, the Satsuma, Tosa, Choshu, Tsu and Saga clans. These denominations are very alien to the cultural heritage of an average western user, and the choice of the various factions may respond to criteria that have no specific cause, as there are no starting emotional points driving it. I will not go into the place names of the regions, or those of the large islands of the arachipelago, from Hokkaido to Honshu - the largest of them- and I will not refer to the old provinces of Tosan, Hokuriku, Tokai, Kinai...

58. There is a naval tactics and strategy video game set precisely at this moment: Ironclads 2: Boshin War (Totem Games, 2017). 
Tsushima, or the present day prefectures, with the exception of Fukushima, ${ }^{59}$ where the disaster of the nuclear power plant occurred after the 2011 tsunami.

But it is in the historical video games based on the great 20th century conflicts where this identity issue as the basis for choice and selection took on a very specific dimension. Choosing one side or the other of the trenches in the "Great War" does not outline the selection problem clearly, as it becomes a simple liking case. The case of 11-11. Memories Retold (Aardman Animations-Digixart, 2018) is not the best one, as that conflict is considered one of the best examples for the antiwar discourse, and this title reflects it as few do. In fact, the choice is simple: a Canadian soldier photographer or a German father who enlists in order to find his missing son. That story contrary to war was not only a cinematic masterpiece of All Quiet on the Western Front (dir. L. Milestone, 1930), ${ }^{60}$ Paths of Glory (dir. S. Kubrick, 1957), or, more recently, War Horse (dir. Steven Spielberg, 2012), Joyeux Noël (dir. Chr. Carion, 2005), The Trench (dir. W. Boyd, 1999) or 1917 (dir. S. Mendes, 2019); it also shows that the interwar period was responsible for defining this great war tragedy as a world drama -an explanation for many historians of the origin of the Second World War. ${ }^{61}$ The objective of this study is not to refer to the factions eligible in the video games set in the latest conflict, but mostly it is the American option the usual one in shooter productions and graphic adventures. The possibility of choosing the Axis countries is resticted to naval, aviation and tank simulators - rather scarce in the latter case. The causes were systematically and thoroughly analysed by Venegas Ramos, who concluded that the story of the war was defined by the cinema, generally made by the American industry and which has been shared by the rest of the companies developing video games, as they have copied a preexisting model. ${ }^{62}$

As we can see, the options are enormously reduced in the video games set in the 20th and 21st centuries, particularly if we compare them with the analysis object of this study: those set in the medieval period. Therefore, it is now important to

59. I mention this island -in fact, three islands separated by channels-, located in the strait of the same name and included in the Strait of Korea, which separates Japan from the Korean Peninsula, because video game users may have heard it in connection with the title Ghost of Tsushima (Sucker Punch Productions para Sony-PS4, 2020), set in the 13th century Mongol invasion and with the famous and decisive battle in the Russian-Japanese war of 1904-1905, about which there is another specific title: Clad in Iron: Sakhalin 1904 (Totem Games, 2018). A good approach to this conflict is offered by Juan Vázquez García in Guerra ruso-japonesa. 1904-1905. Valladolid: Galland Books, 2020. The naval battle has also been taken to the graphic arts of comics with an issue in the collection "Las grandes batallas navales" of Norma Editorial (Barcelona, 2019), a work by Jean-Yves Delitte and Giuseppe Baiguera, intitled Tsushima; a dossier containing historical information is included as well as in the rest of the collection.

60. Based on novel of the same title by Erich Maria Remarque, thas also a remake shot in 1979, directed by D. Mann, although it was designed as work for television from the beginning. There seems to be another project, this time in German, starring Daniel Brühl and directed by E. Berger, the premiere of which is due in 2021. Aller, María: “Daniel Brühl, en el remake de la película "Sin novedad en el frente»". Fotogramas. 18 February 2020. <https://www.fotogramas.es/noticias-cine/a30975068/danielbruhl-remake-sin-novedad-en-el-frente/>.

61. There is a trend towards considering both conflicts as a single one, and even towards identifying them as a civil strife. Comellas, José Luis. La guerra civil europea (1914-1945). Madrid: Rialp, 2019.

62. Venegas Ramos, Alberto. La II Guerra Mundial y el videojuego. Murcia: Editum, 2021. 
answer the second question: why do we want to play a title classified as historical medieval?

\section{Choosing the Game}

The result of analysing a decision can become interminable, as it is multicausal and has factors that could be framed under the scope of simple free will or a momentary situation. In this study, one of the questions raised as its ultimate objective is answering the reasons why an average user chooses one type of game and not another, and, specifically, one set in a more or less plausible historical past. We centre the perspective of the user who seeks to spend their leisure time in this medium of cultural expression if, to that factor, we add that their decision rests with one whose historical context is identified as a medieval period or inspired by it. It is important to raise this question as that first decision - "I want to play a historical video game" - is complemented, in a second stage, with that of choosing one addressing the medieval epoch. The reasons why our society is attracted thus, in general, have no defined cause. González Jiménez referred to this issue already a few years ago. ${ }^{63}$ I also alluded to the gamer's initiative when they are trying to opt for spending their leisure in a game characterised by sociability and a particular sensitivity, that is, enjoying some iconography identified with a more or less imagined Middle Ages and the interest in History. ${ }^{64}$ Since a few years ago it has been assumed that a user is prompted to choose a title by its story and plot, even before its price and the fact that it is easy and quick to play. ${ }^{65}$ The interesting thing to me, as a medievalist, is to observe why a gamer opts for a video game set in the medieval period, and, attention!, in what specific period and civilisation, as has been pointed out above. There is no doubt that the Middle Ages is crucial to understand our idea of civilisation and is the certain origin of a great part of our territorial demarcations, as well as of our local, regional and even national roots.

We can link this identity factor, sifted through what happened later in the 19th century —as is the Catalonian case-, to the medieval period or take it further and

63. González Jiménez, Manuel. “Percepción académica y social de la Edad Media. Un siglo de historia e historiadores". La Historia Medieval hoy: percepción académica y percepción social, XXV Semana de Estudios Medievales de Estella. Pamplona: Ediciones Gobierno de Navarra, 2009: 60-61.

64. In one of his works Íñigo Mugueta Moreno addresses the discussion in Twitter related to the conquest of Navarre in 1512: "History popularised and Tweeted: Emotions and Social Representations around the Conquest of Navarre in 1512". Imago Temporis, 12 (2018): 57-90. This example is useful to us in order to show the current interest in issues from the past where those feelings emerge in a group. The use of History refers to the presence of memory in particular and group cases, in David Lowenthal's words ( $E l$ pasado es un país extraño. Madrid: Akal, 1998), used by the Navarran historian himself.

65. Jiménez Alcázar, Juan Francisco: “The other possible past: simulation of the Middle Ages in video games". Imago Temporis, 5 (2011): 493. 
sink it into the "clan"sense ${ }^{66}$ It is not strange that people look for games seeking to satisfy that recreation yearning or that demand of a past identifying a person with what they are or expect to be. It is the culmination of the products for personal consumption: a past that suits us, as those things we had wanted to happen can become real in a virtual recreated way. The identification with the selected faction is deeply rooted in that choice. A clear example is the game Blocks! Hammer of the Scots (Avalon Digital, 2020), set in the war between England and Scotland at the end of the 13th century. A Scottish video gamer - this is an a priori opinion-will almost always choose the faction of Robert the Bruce's old kingdom. The DLC on the Spanish War of Independence during the Napoleonic campaigns in Napoleon: Total War (The Creative Assembly, 2010), entitled Campaña Peninsular, has been one of the titles that suggest a counterpoint to the one offered in the original game, where managing the French faction allows the gamer the possibility of submitting the Spanish nation or, on the contrary, of getting rid of the French yoke. The feelings and emotions will not be the same for a French and a Spanish gamer when playing this title and its DLC mentioned. I need to add only a premise here, and I would like to insist on it: we are dealing with a game, and the issue I intend to address in this study is the process originated when it stops being only that to become something else, the reflection of an emotion or a feeling.

However, in that generic Middle Ages, a Ukrainian, a Russian, a Lithuanian, a Pole, a Hungarian, a Bulgarian, etc., have the same identity process as any of the Western European inhabitants. This is quite interesting as I centre it in that more or less delimited space which is Western Europe, where the concept of the medieval originated.

When we allude to the nations born in the 19th century wave across the length and breath of America, those roots open into a more or less wide range according to the people or nation in question. The Hispanic, or Iberian, essence separates from the Anglosaxon and Central European essences, whether we allude to Germans, Poles or Austrians, Italians or Greeks... to converge, in some cases, with the native people in that continent. The current empowerment trend of the indigenous cultures to the detriment of the later contributions is but a distortion of the historical reality. This comment has no further intention and depth than to portray a proven and provable fact. Even in these cases - and this phenomenon can be observed in far west films - for many years the public identified with the white Anglo-Saxon people and not with the Indians. "The Cavalry Has Arrived" has even left an expression we all understand. The revisionist activity, a fair treatment in this case, has brought out into the open that the identity of "white man, good" and "Indian red skin, bad" in this historical American period does not do justice to the reality precisely. This

\footnotetext{
66. Sabaté Curull, Flocel. "Constructing and Deconstructing the Medieval Origin of Catalonia". Historiography and the Shaping of Regional Identity in Europe. Regions in Clio's Looking Glass, Dick de Boer $\delta$ Luís Adão da Fonseca, eds. Turnhout: Brepols, 2020: 257-281. By the same author: "Catalan Identity Discourse in the Late Medieval Mediterranean: Creation and Contrast with Neighbouring Identities". Memories in Multi-Ethnic Societies: cohesion in Multi-Ethnic Societies in Europe from c. 1000 to the Present, Przemyslaw Wiszewski, ed. Turnhout: Brepols, 2020: 349-368.
} 
example - and I go on with a historical phenomenon which is a little distant in time but directly affects some countries at present, like everything that happened in the 19 century - can be completed with the title Liberty or Death (Headquarter S.L., 2020). The events this game is based upon are those generated by the independence process of the Ibero-American republics in the first decades of that century: "The gamers are the patriots who fight for their freedom, or the 'Realistas', who are trying to maintain the empire under Spanish control. Who will win?" This is what can be read in the advertising text of Steam. In the options there is the possibility of choosing "nation", and the paragraphs included in the game once the desired campaign has been chosen are a good proof of that emotional challenge. In the campaign "Early years", we can read: "Patriots: Lead the brave Latin American patriots and win their final independence from the Spanish oppressor"; or "Realistas: You are in command of the troops of the Spanish viceroyalties in America, of the Spanish army and navy. Lead your veterans and show the rebels the strength of the powerful Spanish Empire".

In the campaign of "La Plata 1810": "Patriots: lead your brave patriots of Argentina, Eastern Strip, Chile and Peru and win their independence from the Spanish oppressor", and in "Realistas: You are in command of the troops of the viceroyalties of Peru and La Plata. Lead your veterans and show the rebels the strength of the powerful Spanish Empire". Few more comments can be added to what these sentences show up. On the occasion of the centenary of the independence declaration of each of the republics, private initiatives and public institutions have taken advantage of the event to develop titles to serve various ends; but all of them keep the background of the exaltation of the national identity. ${ }^{67}$

Let us stay focused again on the videogames set in the medieval period in all their chronological extension. The choice of the game will be based, in all likelihood, on the user's particular tastes, as the iconographic diversity, and the variety of events, civilisations and cultures, as well as of personages, are enormous. Take, for example, the feudal phenomenon, which, no doubt, characterises the central medieval period in the West. At some point I have turned to this resource, and now it is appropriate to bring it up again here. In the guide for the physical game of Crusader Kings (Paradox Interactive, 2004) one could read: "To understand Crusader Kings, you must understand the medieval feudal system and the hierarchy associated". ${ }^{68}$

In this kind of productions, like in the two titles of Medieval Total War, where the chronological option is framed among the possibilities of the game, that attractive

67. As an example, see the study by Manuel González Manrique about the Mexican case, not with the video game just mentioned, but with others from a few years ago: "Los videojuegos del bicentenario de la independencia de México. Usos y abusos de la identidad, el héroe y la historia", Antropología Experimental, 17 (2017): 305-324. For Argentina, see the educational video game Belgrano-Bit <http://masroboticos. com.ar/roboticaeducativa/belgrano-bit-un-videojuego-sobre-manuel-belgrano/>. For Peru, with the same purposes, see 1814: La Rebelión del Cusco (Grupo AVATAR, 2014); this counted on the active contribution of the historian Antonio Zapata, professor at the Pontificia Universidad Católica del Perú. Link for downloading: $<$ https://sourceforge.net/projects/videojuego 1814/files/Instalador/1814-Ver_1.001-windows-installer. exe/download>.

68. Manual Crusader Kings II... p.25. 
character is broadened for the video gamer who intends to play "the Middle Ages". For example, in $C K$ and $C K I I$ there are two points from which you can begin the game: William the Conqueror's Norman invasion of England, the Third Crusade and the beguinning of the Hundred Years' War. The number of options has increased with DLCs, and in the last title of the series, Crusader Kings III (Paradox, 2020), it is not necessary to resort to those expansions towards the high medieval period, as that is included in the original game, specifically in the year $867 \mathrm{AD}$, in full decomposition of the Carolingian Empire, where the options are staged by Lothair II, Louis the German, Louis II, Charles the Bold and Prince Carloman, Duque of Bavaria.

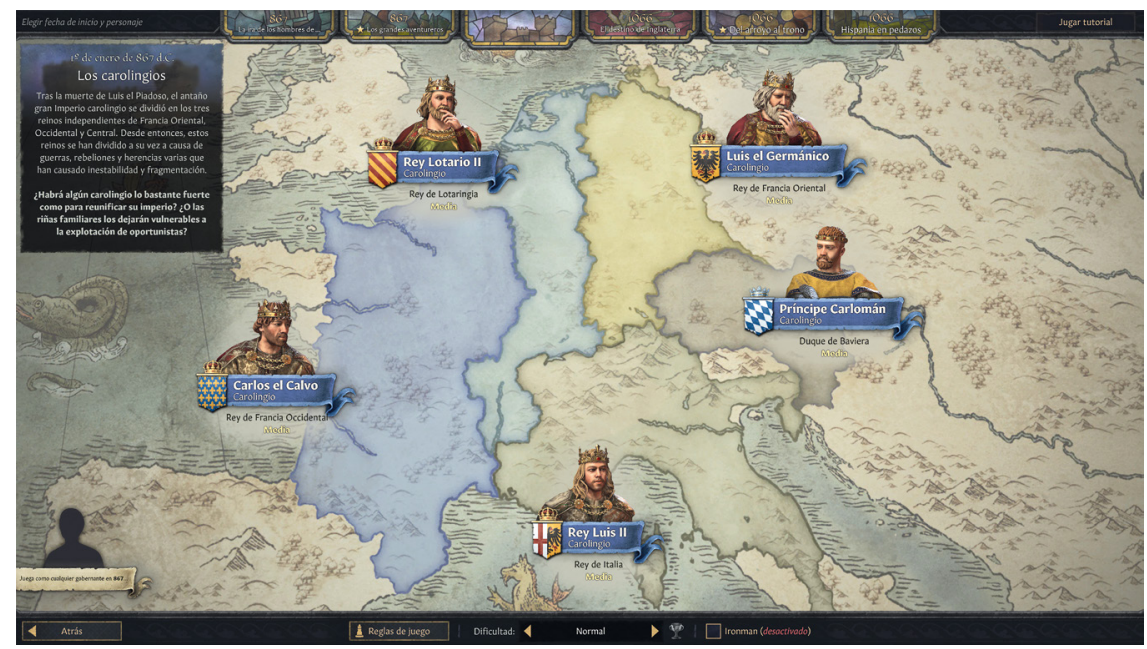

Illustration 6. Factions of the Carolingian Campaign. Crusader Kings III (Paradox, 2020).

Instead, the last stage, the late medieval one, has been eliminated. There is not an important problem for the user either, as there are enough titles to cover that demand, like the one about the Hundred Years' War: Great Battles. Medieval (Slitherine, 2011), where the decision of choosing a side is restricted to the French or English parts (Joan of Arc or Henry V, for example), as was logical enough.

For the case of the Viking civilisation, the user has no difficulty in choosing, even in the strategy games. The emergence of Assassin's Creed. Valhalla (Ubisoft, 2020) has only implied a new impetus in the titles in the Scandinavian civilisation, without a higher incidence for the purposes of this work. What we are really interested in is where the factions of Vikings are involved and appear as selectable, like in Age of 
Empires II: The Age of Kings (Ensemble Studios, 1999), or in Total War Saga: Thrones of Britannia, which have already been dealt with above.

\section{Which of the Factions?}

The game represents the economic, political, religious, and social aspects of the Middle Ages in an astoundingly intricate and accurate manner. Recreate history or charge off into infinite alternate possibilities. The choice is yours. ${ }^{69}$

This text from the already cited guide of Crusader Kings II ultimately summarises the third question posed in this article. The thing is how respond to the definition of the possible reasons why one of the factions is chosen -already within the game- by the user and what it implies or they can do. In fact, that is the key to this discussion about identity and historical games, or, in other words, what drives a video gamer to choose Emirate of Cordova or Kingdom of Asturias in the case of the expansion Charlemagne from Total War: Attila, or what their reaction is when they have to turnthe title down because their "faction" either is not playable or simply does not appear. The solution to this latter case comes from the mods. As it is a global setting where the only limit is the determination of many people who have the wish and the knowledge to alter the original game to their convenience, it is here where the fan phenomenon finds its most evident projection. It is the summit of the consumer goods, made to the exact measure of the final user, as has already been alluded to above.

The options many historical video games offer to the average gamer are conditioned by the earliest designing intentions of the developing studios and by their idea about that past specifically. On the other hand, it is clear that the designer also thinks of that video gamer, as ultimately it will be that gamer who will buy and enjoy the game, suffer from it or is thrilled or upset about it and about what occurs in it, either because of any software faults (any impertinent and impenitent bugs), but particularly because of the quality of the gamer's decisions, which will lead the game to success or failure. This is an important issue as that identification of the gamer with the chosen faction responds to the impetus of emotion. That identity process can be differentiated into three categories as forms of expression:

- Simulated identity, which responds to the desire of wanting to be - the avatar.

- Assumed identity, which is the simple awareness of being, whether correct, adequate, or not. This is the essence of the game identity.

- Inherited identity, which includes a sort of obligation of being, as the reasons that condition tradition or provenance. In this case, it is the feeling of identification with the nation the gamer belongs to or has empathy for, whatever its cause is.

69. Manual Crusader Kings II..., p. 4. 
For the case of the video game - the essence of re-creation, as it is a simulation of the past - the first two are those that have the greater impact, as the avatar phenomenon leads to configuring a predisposition in the user towards a specific choice and the rejection of the rest.

I have focused this study on the video games following a historical script set in the medieval period, and, although I have alluded sometimes to situations similar in those set in the Ancient, Modern and Contemporary Ages, it is not exclusive of this sort of productions, where the video gamer receives all the power of the "past", but it is the essence of the medium, where that interaction finds its own place. In the collector's edition of The Last of Us II (Naughty Dog, 2020), a title of the survival horror gender, with action-adventure and shootings in the third person (third-person shooter), we locate a small album containing a spledid illustration and a text meant for the user which poses the following questions:

"What would you do if someone you loved was the victim of cruel and violent act? How easily could one's mind tip toward violent retribution? How far would you go to bring the people responsible to justice? If you were successful, how would it change you? Would you ever be the same?"70

This is a text signed by Neil Druckmann, the creative director of that video game, which does not leave us unmoved and leads us to one of the targets proposed in this article: the video gamer's decision, not only made after calculating its factors but with something else more difficult to quantify: the feeling of the most primary initiative. Obviously, if something is anthropologically primitive, that is the membership to a group, the essence of what identifies a person with their neighbours and, at the same time, differentiates them from those not belonging to that group. Now it would be advisable to indicate the size of that human aggregate, as we can extend it from a single individual to a crowd or social mass. For a video game - the titles facilitating collaboration - that individual identity has the same projection. If the identity quest leads to particular solutions, what is sought here is merging with initiatives, tastes and emotions which are similar to shape that nuclear group. ${ }^{71}$

It is true that in ancient societies the concept of alterity was very limited, and it is not a forgotten issue. Greeks and Romans and their barbarians; Jews and gentiles - goyim —; the Japanese and the gayjin; the Chinese and gwailo...; or Christians and pagans, or Muslims and unfaithful... in periods which may be far away from us or nearer to us... all of these denominations mark people's belonging to us and them. It is on this aspect that I want to insist, as on many occasions that identification caused by diverse factors will result, with a false perspective, in choosing one or the

\footnotetext{
70. The text appears on two different cards, in Spanish and English. Obviously it is intended to satisfy the users of both linguistic cultures.

71. García de Cortázar y Ruiz de Aguirre, José Ángel. “¿ "Atomización»? de las investigaciones y ¿ «regionalismo»? de las síntesis en Historia Medieval en España: ¿búsqueda de identidades o simple disminución de escala?", La Historia Medieval hoy: percepción académica y percepción social. XXV Semana de Estudios Medievales de Estella 2008. Pamplona: Gobierno de Navarra, 2009: 343-380.
} 
other side. There is no place here for the most historicist essence of the reality of a truthful past as it is the purest emotion. It is not the head that is speculating abut the choosing process: it is the soul, the heart, that thinks directly. This phenomenon has always existed, and, centred in the medieval period, we can document quite a lot of examples, from the "nation of the Goths" in front of the Muslims as referred by Alcuin of York, ${ }^{72}$ to the "Catalonians" mentioned in the Crónica de Fernando IV when recounting the loss of the kingdom of Murcia to Jaime II at the end of the 13 th century. ${ }^{73}$

The game containing some of the places one recognises increases its intensity if the title is set in a specific time. Cordova or Tarraco are not neutral places for Spanish video gamers if they play Imperivm Civitas III (Haemimont-FX, 2008), ${ }^{74}$ as they appear as possible sites for the establishment of a Roman ex novo colony, in the same way as a specific identification with a certain faction is assumed because of one's birth or provenance. The place of some settings achieves the same effects. The use of feelings and emotions to generate an identity setting is quite versatile in the setting of a video game, as it contributes to the immersive capacity of the title. Quite an evident example, centred in the medieval period, is that of the expletives made by Henry and his friends while throwing manure balls at a dwelling owned by a German at the beginning of Kingdom Come: Deliverance (Warhorse, 2018): “iComed mierda, teutones!" ("Eat shit, you Teutons!") in its Spanish version. ${ }^{75}$

This title is significant enough, as its cataloguing as RPG differs from the approach so far, since I have alluded almost exclusively to strategy titles. Thre is an explanatory text, within the information offered by the game, which summarises the consideration of a "foreigner" in early 15th century Bohemia, in the medieval period, the time when the title is set. But the interesting thing is the reference to the contact with the Germans:

"From ancient times, the word "foreigner" referred not only to someone coming from outside of the city or village (and who was, therefore, a potential enemy) but also to any person with no special legal status (...) The lands of Bohemia were open to foreigners, relatively and for a long time, and have a lively commercial and cultural exchange (...) Their relations with the Germans were neutral at the beginning, later they cooled down and ended with

72. García Moreno, Luis. “Los Hispani: emigrantes y exiliados ibéricos en la Francia carolingia. Realidad y mito historiográfico". Movimientos migratorios, asentamientos y expansión (siglos VIII-XI). En el centenario del profesor José María Lacarra (1907-2007). Pamplona: Gob. Navarra, 2008: 53.

73. “En este tiempo mesmo movió el rey de Aragón con su hueste e fue al reyno de Murcia, e por consejo de los de la tierra, que eran catalanes, dieronsele todas las villas e los castillos, salvo ende Lorca, que moravan castellanos, e otrosi Alcalá e Mula". Crónica de Fernando IV, chap. II: 32. Translated by Antonio Benavides, included in the Memorias de Fernando IV de Castilla, vol. I. Madrid: Real Academia de la Historia, 1860: 1-243.

74. It is marketed by Steam as Grand Ages: Rome (only in English, French and German).

75. About the complex relations in this central European area over the early years of the 15th century, see Velička, Tomáš. “Three Languages, One Town: Linguistic Aspects of Written Communication between the King and Bohemian Royal Towns in the Fourteenth and Fifteenth Centuries". Memories in MultiEthnic Societies. Cohesion in Multi-Ethnic Societies in Europe from c. 1000 to the Present, Przemvysfaw Wiszewski, ed. Turnhout: Brepols, 2020: 369-407. 
animosity "against everything German", although still very distant from the 19th century strident nationalism. The plague and the mid 14th century diseases affected migration, and fewer foreigners arrived in Bohemia. During the wars against the Hussites, almost every city and town had a majority of Czech citizens. Only the main centres in Moravia still were Germans: Brno (Brün), Jihlava (Iglau) and Olomouc (Olmütz). The Czech language was gradually penetrating from rural society to the highest social layers. The Hussite war produced a fundamental change in the way the language and the ethnic group were seen, since most Czech speaking people identified with the Hussites, whereas most Germans supported Segismund and the Pope. This feeling was exacerbated by the foreign crusades (often German) called by Segismund against the "upstart Hussites'".

In this case that identity is marked by the express wish of the director of the project, Daniel Vávra. What is most interesting for a medievalist is their desire to create a title intending to achieve a most accurate historical veracity, always under the paradigm of the playability factor, a question inherent in any videogame. ${ }^{76}$ Those not veiled emotions in the game - in fact, they are its essence- are shown differently when they are symbols or icons reproduced by the developers precisely

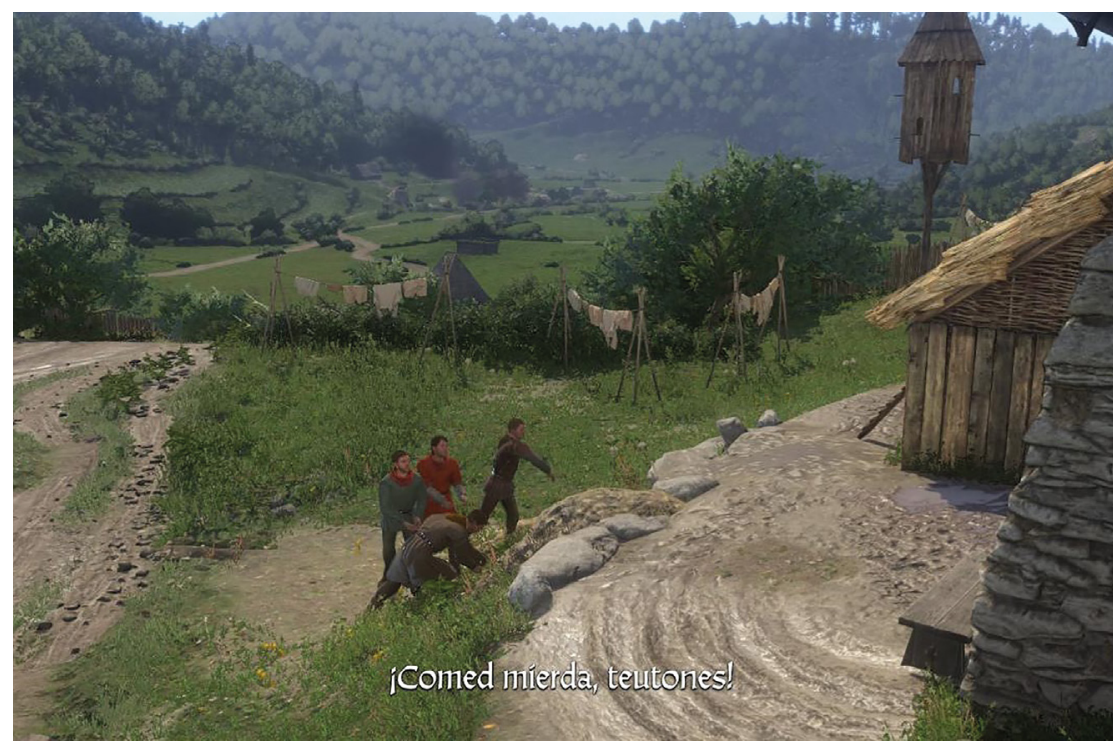

Illustration 7. Henry and his Friends in SkaLitz -Stribrna Skalice actual一. Kingdom Come: Deliverance (Warhorse Studios, 2018).

76. Bostal, Martin. “Medieval video games as reenactment of the past: a look at Kingdom Come: Deliverance and its historical claim". Del siglo XIX al XXI: tendencias y debates, Actas XIV Congreso de la Asociación de Historia Contemporánea, Mónica Moreno, coord. Rafael Fernández, Rosa Ana Gutiérrez, eds. Alicante: 
for the immersion and truthfulness of the game, if that is the designer's ultimate intention. These images are, in a specific way, those looked for by the users in order to achieve that identification. ${ }^{77}$

Among the reasons leading users to choose a certain faction, is, no doubt, the iconography they want to find in the game. I alluded to the coats of arms in some factions of Medieval II: Total War and their manifest errors, and the corrections of them lead to some initiatives intended to make those "tweaks": mods also seek to achieve those identifications. In one made for this same game and entitled Medieval Spain (La España Medieval) we can find the Christian factions of Castile, León, Navarre, Aragon, Galicia, Portugal, County of Barcelona, County of Urgell, County of Tolosa (Toulouse), France, Dominion of the Cid and England; and the Muslim ones of the Almoravids and the Almohads: kingdom of Granada, taifa of Seville, taifa of Zaragoza, taifa of Toledo, taifa of Badajoz, taifa of Granada, Ziris and Merinis, in correspondence to the various campaigns that can be played and are distributed chronologically into five periods after the decomposition of the Caliphate.

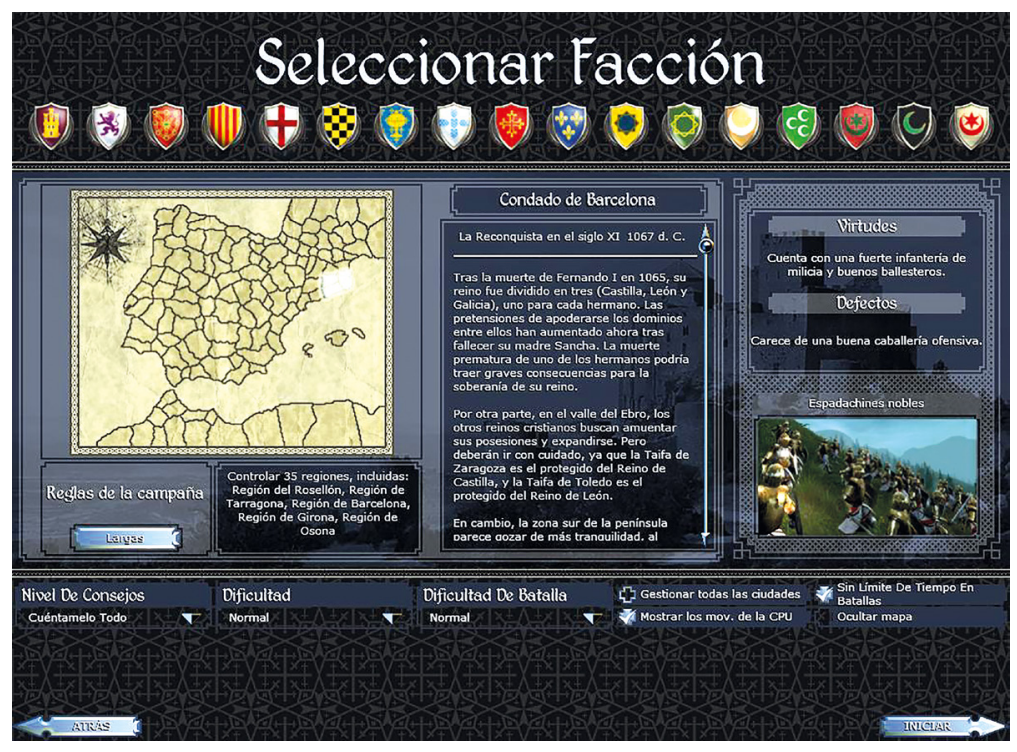

Illustration 8. Factions of the mod ReConquest. MedieVAL II: Total WaR.

Biblioteca Virtual Cervantes, 2019: 380-394. <https://rua.ua.es/dspace/bitstream/10045/95829/1/XIVCongreso-Asociacion-Historia-Contemporanea_00-380-394.pdf $>$.

77. See note 42 . 
The search for that recreation of the past is the objective of the user, who, if they so wish, can achieve an emotional identification with a past which is now within reach, and its images are essential for this process. In this mod, the Christian coats of arms are certainly accomplished, whereas the Andalusian ones are more than questionable in most cases. A Spanish user has a lot to choose from, no doubt, even from that mystic duality of the purported cultural coexistence they may assume. ${ }^{78}$ However, that Spanish identity, more or less "territorialised", is deeply rooted in the configuration of those spaces, which were all gestated in the medieval period, where the concept of "frontier" is inherent to that process. ${ }^{79}$

When banners and flags are already assumed as guides and identifiers of a territory or faction also appear in the video game, in fair correspondence with what is expected to show up in it. The flags of the late Middle Ages and, especially, those of the Modern Age, are something customary in video games, although sometimes they are not very accurate either. In Port Royale 4 (Gaming Minds Studios, 2020), the Spanish flag of 1580 is the two-coloured one; and it is not the only case, as it also occurs in Empire: Total War. But we know that it started as flag of the navy during Carlos III's reign and became the official flag of the country by a royal decree under Isabel II, in 1843. The white background banner with the cross of St. Andrew, or Burgundy Cross, appears in the Mesoamerican dominions depending on the Spanish faction, but the red and yellow national flag is still used. These are details which erode that identifying process besides taking away historical veracity, which is sacrificed by the developers in their own interests in order that average users link that specific faction to the national flag they already know - Spanish users, that is. It is the same case as when, to support that alleged playability, the developer combines Castilians and Aragonese into the same faction in the same full and late medieval period with the exclusive denomination of "Spanish", as I noted earlier for the case of Medieval II: Total War and its innaccurate banner.

\section{Conclusions}

Once the user has chosen a video game, particularly a historical one, they have various emotions classified in varying degrees, but we could combine them into one of "challenging". They may win or lose but have a pleasure or annoyance response,

\footnotetext{
78. Xavier Andreu Miralles' reflections on Spanish medieval past when trying to configurate a Spanish identity in the 19th century are quite interesting: El descubrimiento de España. Mito romántico e identidad nacional, Barcelona: Taurus, 2016. He takes up the baton from José Álvarez Junco's masterpiece, Mater dolorosa. La idea de España en el siglo XIX, Madrid: Taurus, 2001. It is advisable to consult, by the latter author, "La historia en el origen del debate identitario. De Unamuno a Ortega", De la idea a la identidad: estudios sobre nacionalismos y procesos de nacionalización. Estudios en homenaje a Justo Beramendi, Ramón López and Miguel Cabo, eds. Granada: Editorial Comares, 2012: 3-14.

79. Sabaté Curull, Flocel. "Frontera peninsular e identidad (siglos IX-XII)", Las cinco Villas aragonesas en la Europa de los siglos XII y XIII, Esteban Sarasa, coord. Zaragoza: Institituto Fernando el Católico, 2007: 47-94.
} 
not only because of the fact of reaching a goal or not; it may be due to the capacity of their identification with the faction or character chosen. That is the process I have addressed in this study, trying to show that the medium stops being simple entertainment to become an instrument of cultural expression. We must seek its causes in the idiosyncrasy of the game itself, where immersion and interaction are crucial to achieve assimilation with what we play, which is the reason for its success. The user can become identified with their faction or character, in the same way they do it with team games, so that setbacks or annoyance, or satisfaction, are emotions they assume as their own. "We have won..." -we. It is an expression of joy which has nothing to do when there is an inverse development, when eluding a sense of failure: "They have lost..." - they. In the case of a video game, when the user does not win, as it is a medium where they are an inherent part of what happens in it, that is not possible: the user also loses. The fact of choosing a certain faction the video gamer has identified with is the cause of adding to disappointment the fact that it is not only the user who "loses" but "theirs" also fail. On the contrary, the euphoria and well-being of victory are not only individual gains: because of the identification with that "nation" or team chosen, those feelings reach deep emotions. The achievement of that identity is projected onto the selected faction and is the cause not only that you win or lose but that the essence of what you are or the things you believe in win or are defeated.

As an intermediate step for their leisure moment, a video gamer has a clear preference exercise, which, on many an occasion, is guided by the multiple causes of an identification with the faction they are prepared to play. That path, which seems simple a priori, actually is rather winding, as there are various reasons for an election, which, is fequently driven by emotions, feelings or prejudices, difficult to explain from reasonable logic. On other occasions, that definition which has led to a specific option is certainly simple, and has something to do with an identity idea assumed in its most comprehensive character. Let us not forget that the reference is a game. It acquires a sense and meaning further from what is simple amusement, when it becomes the identification with a desire or longing for something that occurred and now the user has the opportunity to recreate virtually. Ultimately, a game stops being that and turns into the expression of a feeling, where the identity phenomenon is a considerable debtor of that reality.

Obviously, this factor is not exclusive of video games: we had already seen it in other entertainment areas, like literature, sport, cinema and music. The difference lies in the interactivity of the medium, as has been indicated. The gamer's direct intervention in titles whose script is in the historical past is the objective of the analysis in this work, but, in this sense, we must not leave team games aside, as the choice is always driven by those same threads of and, frequently, of passion. I alluded to the "me" variable as a basic point. Marketing directors take advantege of it to publicise their productions, so that it is customary to use the second person singular pronoun to place the user in the context of a video game and to offer them also the possibility of controlling the events unfolding in it, whether they are a possible future, either dystopian or not, a present allowing for a different reality, or 
a more or less plausible and truthful past: "Fight in the battle of Navas de Tolosa. Welcome to the 13th century. There is a great deal at stake: your own honour and the destiny of many countries." This is what can be read on the counter cover of the physical game XIII Century, Death or Glory (1c Company, 2008). It is another instance, like the Crusader Kings mentioned above; another resource recognised by users, who also share that common way of speaking.

Identity is what classifies us as individuals and conditions that choice I have just mentioned. It also does that to us considered as a group; and a great part of that process has been built by historical tradition, which is certainly more linked to clans and territories. The digital technology that supports the essence of video games allows for a virtual recreation of the past a user can become identified with, whether it is due to the admiration or empathy for a personage or on the grounds that they have assumed they belong to that "tribe", ficticious - fan phenomenonor not.

Another customary resource for promoting historical video games is the gimmick of "getting to know" or "embody" some historical personage, such as a king or some political leader. In this particular instance, the medieval period, we count on a lot of examples, like the text that appears in Real Warfare Anthology. Grandes batallas medievales. ${ }^{80}$ The "admiration" factor intervenes here in a very active way, but is much less important if we talk about a nation-faction we are direct or indirect inheritors of. A good deal of those territorial identities were generated in the medieval period and were consolidated in the 19th century through processes associated to nationalism, regionalism and localism. Later studies attempted, and are attempting, to analyse those processes, and, along with a very consolidated visual and conceptual iconography of what "the medieval" is, carry a hybrid basis the developers of historical games extract their scripts from: Castile, Aragon, England, Navarre, Scotland..., if we refer to the titles set in the period prior to the 10th century, or the European monarchies in the Modern Age. As for the Japanese factions in the Sengoku period or the countries and empires already very well defined in the 19th and 20th centuries, the resource to the past is just the same. It shows the possibilities the designers of these historical video games offer to get the attraction and interest of the users who precisely demand titles set in certain historical moments and those attracting our interest - those of a clearly medieval context.

The identities of many users are recognised in those historical video games, since they are associated, in a virtual way, to a common past which places them historically. Each period particularly affects certain groups and territories, not to mention specific nations, as it is quite evident that video gamers are appealed by the temporal closeness in question. Clear examples of this are the titles set in the Second World War, and those of the Spanish Civil War. Emotions are defined as an essential element when referring to the identity phenomenon; and the appropriation

80. “It embodies historical figures like King Alfonso VIII of Castile, Pedro II of Aragon, Philip II of France or Edward I of England" ("Encarna a figuras históricas como el rey Alfonso VIII de Castilla, Pedro II de Aragón, Felipe II de Francia o Eduardo I de Inglaterra"). Guide for the video game, p. 4. It is a reedited version by the FX Interactive distributor of the already mentioned XIII Century. Death or Glory, sea note 40. 
of a common past is what conditions that identification process with a cultural substratum a user identifies with.

This issue generates more debates than solutions; but it is important that such questions are addressed by historians, and in a particularly higher degree by medievalists. Hence the decision of addressing it because of the great impact of video games, especially those with medieval scripts, upon the younger generations and will end up by outlining certain kind of History if we do not assume the responsibility of opening up debates which serve us as reflexion guides in our discipline.

\section{Addendum}

Imagine that on seeing the text of Kingdom Come: Deliverance and the illustration accompanying it —see Illustration 7-, instead of "Teutons" it said "Catalonians" if you are a Catalonian, or "Andalusian" if you were Andalusian, or French if you were French, or Murcian if you were Murcian... In the case you felt annoyed, in some way, you will understand the ultimate objective of this work, certainly interactive. 